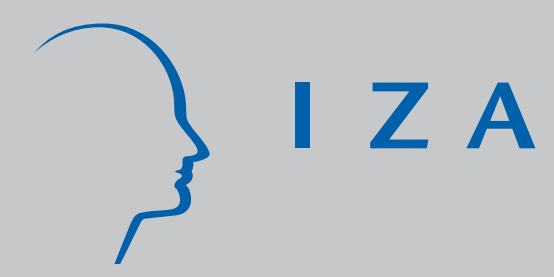

IZA DP No. 2792

Entrepreneurship and Survival Dynamics of Immigrants to the U.S. and their Descendants

Dimitris Georgarakos

Konstantinos Tatsiramos

May 2007 


\title{
Entrepreneurship and Survival Dynamics of Immigrants to the U.S. and their Descendants
}

\author{
Dimitris Georgarakos \\ Goethe University Frankfurt and CFS \\ Konstantinos Tatsiramos \\ $I Z A$ \\ Discussion Paper No. 2792 \\ May 2007
}

IZA

P.O. Box 7240

53072 Bonn

Germany

Phone: +49-228-3894-0

Fax: +49-228-3894-180

E-mail: iza@iza.org

\begin{abstract}
Any opinions expressed here are those of the author(s) and not those of the institute. Research disseminated by IZA may include views on policy, but the institute itself takes no institutional policy positions.

The Institute for the Study of Labor (IZA) in Bonn is a local and virtual international research center and a place of communication between science, politics and business. IZA is an independent nonprofit company supported by Deutsche Post World Net. The center is associated with the University of Bonn and offers a stimulating research environment through its research networks, research support, and visitors and doctoral programs. IZA engages in (i) original and internationally competitive research in all fields of labor economics, (ii) development of policy concepts, and (iii) dissemination of research results and concepts to the interested public.
\end{abstract}

IZA Discussion Papers often represent preliminary work and are circulated to encourage discussion. Citation of such a paper should account for its provisional character. A revised version may be available directly from the author. 


\section{ABSTRACT \\ Entrepreneurship and Survival Dynamics of Immigrants to the U.S. and their Descendants}

Many studies have explored the determinants of entering into entrepreneurship and the differences in self-employment rates across racial and ethnic groups. However, very little is known about the survival in entrepreneurship of immigrants to the U.S. and their descendants. Employing data from the Survey of Income and Program Participation, we find a lower survival probability in entrepreneurship for Mexican and other Hispanic immigrants, which does not carry on to their U.S.-born descendants. We also find that these two immigrant groups tend to enter entrepreneurship from unemployment or inactivity and they are more likely to exit towards employment in the wage sector, suggesting that entrepreneurship represents for them an intermediate step from non-employment to paid employment.

JEL Classification: $\quad F 22, \mathrm{J15}, \mathrm{J} 82, \mathrm{C} 41$

Keywords: entrepreneurship, business ownership, duration analysis, left truncation, immigrant status

Corresponding author:

Konstantinos Tatsiramos

IZA

P.O. Box 7240

53072 Bonn

Germany

E-mail: Tatsiramos@iza.org

\footnotetext{
* The authors would like to thank Barry Chiswick, Don DeVoretz, David Jaeger, Magnus Lofstrom, Pierre-Carl Michaud, Jan van Ours, Stephen Trejo, the participants at seminars at IZA, Univeristy of Milan, the Netspar Workshop in Utrecth, and the PAA 2007 meetings, for many useful comments. All errors remain our own. Dimitris Georgarakos acknowledges partial financial support from the Center for Financial Studies under Research Program 'Household Wealth Management'. Konstantinos Tatsiramos acknowledges financial support from the Volkswagen Foundation for the IZA project on "The Economics and Persistence of Migrant Ethnicity".
} 


\section{Introduction}

Self-employment rates across racial and ethnic groups differ substantially in the United States, where Hispanics and African-Americans exhibit lower rates compared to Whites and Asians (Fairlie and Meyer 1996). Self-employment can be an important determinant for migrants' success and well-being in the host country and may even offer an avenue for escaping poverty for the more disadvantaged groups. Recently, Hotz-Eakin, Rosen and Weathers (2000), have presented evidence of stronger upward mobility in the income distribution among low-income self-employed workers compared to low-income wage/salary workers, and Fairlie (2004) has documented faster earnings-growth for the former group. Looking at different racial and ethnic groups, Hispanics and African-Americans perform worse in terms of earnings compared to Whites and Asians (Fairlie, 2005). There is also evidence of heterogeneity in terms of asset holdings among immigrants, with Europeans and Asians having substantially more wealth than the average immigrant (Cobb-Clark and Hildebrand, 2006).

While there is an extensive literature on the determinants of business ownership, which has emphasized the role of wealth holdings ${ }^{2}$, relatively few studies examine survival into entrepreneurship. Recent attempts in explaining the observed differences in self-employment rates among minorities and disadvantaged groups have focused not only on the transitions into but also on those out of entrepreneurship. Fairlie (2005) finds that disadvantaged groups have relatively low rates of entry into and high rates of exit out of self-employment. Lofstrom and Wang (2006), focusing on the comparison between Mexican-Hispanics and other Hispanics, find no significant differences in their entry rates, but lower survival probabilities for

\footnotetext{
${ }^{2}$ For example, see Evans and Jovanovic (1989), Evans and Leighton (1989), Quadrini (1999), Gentry and Hubbard (2004), who are documenting a positive effect of wealth on the probability of starting a business. This has mainly interpreted as an indirect evidence for the existence of liquidity constraints that impose barriers to new business formation. An exemption is Hurst and Lusardi (2004) who find a positive relationship between wealth and the propensity to start up a business only for the top five percent of the wealth distribution.
} 
Mexican-Hispanics. Both these studies adopt a static framework to analyze year-to-year transitions.

Given the importance of exits from entrepreneurship in understanding the observed differences in self-employment rates among racial and ethnic groups, in this paper, we investigate the survival dynamics of immigrants to the U.S. and their descendants. Existing literature has already pointed to the strong intergenerational links underlying self-employment rates, suggesting that disparities in the previous generation tend to be reproduced to the next one (see for instance, Fairlie 1999 and Hout and Rosen 2000). Intergenerational mobility and differences in earnings between first and second or higher generations have been also analyzed (e.g. Borjas,1993; Chiswick, 1977; Trejo, 2003). However, very little is known on the differences in survival into entrepreneurship between immigrants (foreign-born) and descendants of various immigrant groups (U.S-born).

We employ duration analysis which contributes to the existing literature by providing a dynamic framework that addresses the shortcomings of the static binary choice models. Namely, their inability to take into account the fact that the stock of entrepreneurs initially observed represents a selected sample (left-truncated) of those successful enough to survive up to that point. Ignoring such a selection mechanism might lead to biased inference, which we show that can be important in this context. Furthermore, we extend the duration analysis to examine exits to different states, that is, exits to employment in the wage sector or to nonemployment, and the extent to which they differ between immigrants and their descendants.

We find a lower survival probability in entrepreneurship for foreign-born Mexicans and other Hispanics compared to non-Hispanic whites. However, such differences in survival do not carry on to the U.S.-born descendants of these two immigrant groups. In addition, we find that Mexican and other Hispanic immigrants tend to enter entrepreneurship from unemployment or inactivity, and they are more likely to exit towards employment in the wage 
sector. This suggests that entrepreneurship represents for them an intermediate step from nonemployment to paid employment. On the other hand, African-Americans who also exhibit a lower survival in entrepreneurship, show a higher propensity to exit to non-employment. The above findings provide a better understanding of the observed gap in self-employment rates and are relevant for existing policies that target entrepreneurs from disadvantaged groups.

The analysis is based on data from the Survey of Income and Program Participation (SIPP) using the 1996 survey. SIPP is particularly well-suited for our study given that it is a panel which provides information on monthly basis, and offers detailed information on immigrants. Its main advantage is that the exact date of starting up a business is known. This allows us to construct business ownership durations and adequately control for the lefttruncated spells.

The rest of the paper is organized as follows. The details of the data are discussed in Section 2, while Section 3 describes the empirical hazard and survival functions based on the data. Section 4 presents the econometric model and Section 5 the empirical results. Section 6 offers concluding remarks.

\section{Data}

The empirical analysis is based on the 1996 panel of the SIPP. The 1996 survey is a rotating panel collected every four months for approximately 36,700 U.S. households spanning over a 4 year period. Each wave of the SIPP contains both core questions common to each wave and topical questions that are not updated in each and every wave. The core questions provide information on business ownership for each person in the household above 16 years old and 
the exact starting date of the business. Knowing the exact starting date is important for constructing exact spell durations. ${ }^{3}$

The additional advantage of using the SIPP is that it contains a migration module in wave 2 of the panel. Based on the information about the country of birth in the migration module, we are able to distinguish between U.S. born and foreign-born individuals. For the latter group, we consider different groups of immigrants, namely, Mexicans, other Hispanics, Europeans (including Australians and Canadians), and Asians. Furthermore, using the available information about the ethnic origin of individuals, we also distinguish the U.S.-born in the following groups: Mexicans, other Hispanics, African-Americans, Asians, and nonHispanic whites ${ }^{4}$. Those U.S.-born individuals with a foreign ethnic origin are considered as the descendants - second or higher generation - of the foreign-born..

SIPP data also provide information on wealth at the household level in waves 3, 6, 9, and 12. From the assets and liabilities module we use household's total net wealth which is equal to total assets minus liabilities. Although the SIPP contains detailed information on specific assets and liabilities, it does not gather information about assets held off-shore which may be particularly important for immigrant households, but this is a limitation shared by all other available data sources, such as the PSID (Cobb-Clark and Hildebrand, 2006).

We obtain an unbalanced panel for those who entered the sample in the first wave of 1996. We make this restriction as the migration module is only asked at wave $2 .^{5}$ Multiple spells (owning more than one business) for each individual are taken into account. The sample

\footnotetext{
${ }^{3}$ The PSID, which also contains immigration history information and wealth data, does not provide the day of entering into business. Therefore, any analysis needs to be based on an inflow sample since 1998, when a representative sample of 491 immigrant families was included in the survey, which would lead to a very small sample.

${ }^{4}$ In what follows, U.S.-born descendants of European immigrants are considered as non-Hispanic whites. We also distinguish the group of African-Americans in order to separate them from the reference group of nonHispanic whites.

${ }^{5}$ The remaining sample represents about $90 \%$ of the total sample. We also exclude from the analysis individuals born in Puerto Rico on the basis that their unique legal position makes it difficult to sensibly include them in the foreign-born population, and American Indians as they differ from the Americans and are very few to be included in the analysis as a separate group.
} 
of business owners consists of the stock of those who are owners at the first wave of the panel, and the inflow into entrepreneurship since then. ${ }^{6}$ The analysis focuses on males, in order to avoid the selectivity issues related to female employment, aged 20-64.

The resulting sample consists of 4567 business spells of which 4094 are owned by a U.S.-born and 473 by a foreign-born individual (10.4 per cent of the total sample). One-third of the spells (1375) end with an exit from entrepreneurship and the rest are right-censored. Table 1 presents relevant summary statistics. The first two columns show that foreign-born individuals are slightly younger, less educated, more likely to be married with more children, and have lower average wealth, income, and business equity, compared to the U.S-born. Considering foreign-born immigrants by origin, we observe that Mexicans have the highest proportion of high school drop-outs (about 60\%), and the lowest wealth and income levels, followed by other Hispanics.

[Table 1]

\section{Empirical Hazard Function and Survival Estimates}

Figure 1 depicts the empirical hazard function based on the Kaplan-Meier estimators. Panel A shows the hazard function for the foreign and U.S-born individuals. The general pattern of the hazard function is non-linear with an increasing exit rate at the beginning of the spell, which declines with the elapsed time into entrepreneurship. The U.S.-born experience a faster initial increase in the hazard rate compared to their foreign-born counterparts, which reaches about 1.5 per cent. After about the first year, the hazard rate of the foreign-born overtakes the U.S.born until they converge. Panel B distinguishes between U.S.-born (i.e. non-Hispanic whites), foreign-born and U.S-born descendants of immigrants. The hazard rate for the U.S-born

\footnotetext{
${ }^{6}$ The way to deal with the bias that arises from stock sampling, since only those who have survived in entrepreneurship are observed in wave 1, is discussed in section 4.
} 
descendants initially increases, exceeding 2 per cent around the first year of duration and converges after a year and a half to the levels of the other two groups. In Panel $\mathrm{C}$ we distinguish the foreign-born into four main ethnic groups, namely, Mexican, other Hispanic, Asian, and European. To ease comparisons, we still report the hazard function for the U.S.born descendants of immigrants and the U.S.-born white non-Hispanics as in Panel B. Foreign-born Mexicans and other Hispanics show the highest exit rates, with the Mexicans reaching the rate of 2.5 per cent in the first year. Finally, Panel D depicts hazard functions of the U.S-born descendants of immigrants by ethnic group, suggesting that the large increase on the hazard rate for the U.S.-born descendants in Panels B and C is mainly driven by the U.Sborn Mexicans.

[Figure 1]

Figure 2 displays the survival function which is the percentage of spells surviving into entrepreneurship. The survival function in panel A, which reflects the overall higher hazard rate of foreign-born immigrants, lies below that of the U.S-born. Distinguishing among the four groups of immigrants, Panel $\mathrm{C}$ shows that foreign-born Mexicans have the lowest survival probabilities followed by other Hispanics. Finally, in Panel D, it is the U.S-born Mexicans who exhibit the lowest survival among the U.S.-born descendants.

\section{[Figure 2]}

Although informative, this analysis which is based on the empirical estimates of the hazard and survival functions does not control for all possible factors at work. In particular, the observed differences between the foreign-born and their U.S.-born descendants and across 
ethnic groups might be due to differences in characteristics, such as wealth and/or skills. Moreover, the negative duration dependence that is suggested by Figure 1 might be spurious. For instance, individuals with lower entrepreneurial ability, which is mainly unobserved, are more likely to exit business faster, so that the remaining sample represents a selected group of those with higher ability. These observed and unobserved characteristics might affect the patterns in survival probabilities and duration dependence that we see in the data. To take these differences into account we estimate an appropriately specified econometric model.

\section{Econometric Model}

We investigate the transitions out of entrepreneurship in a multivariate setting by estimating a discrete time hazard function, as outlined in Narendranathan and Stewart (1993) and Jenkins (1995).

Suppose that the transition out of entrepreneurship for an individual $i$ is a continuous process with hazard

$$
\theta_{i}(t)=\lambda(t) \exp \left(x_{i}^{\prime}(t) \beta\right)
$$

where $\lambda(t)$ denotes the baseline hazard, $x_{i}(t)$ is the vector of time dependent and independent explanatory variables, and $\beta$ is a vector of unknown parameters. The discrete time hazard denotes the probability of a spell of entrepreneurship being completed by time $t+1$, given that it was still continuing at time $t$. The discrete time hazard is therefore given by

$$
h_{i}(t)=1-\exp \left(-\int_{t}^{t+1} \theta_{i}(u) d u=1-\exp \left[-\exp \left(x_{i}(t)^{\prime} \beta\right) \gamma(t)\right]\right.
$$

where

$$
\gamma(t)=\int_{t}^{t+1} \lambda(u) d u
$$


denotes the integrated baseline hazard. We do not impose any functional form for $\gamma(t)$, and we estimate the model semi-parametrically. We allow for 12 duration intervals of 6 months each, which cover a duration period of up to 6 years, and an open interval of more than 72 months duration. For normalization purposes we set the coefficient of the first interval to be zero.

As discussed in Section 2, we observe individuals who start-up a business after their first interview (inflow sample) and those who already own a business at their first interview (stock sample). The log-likelihood contribution of an inflow spell of length $d_{i}$ is

$$
\begin{aligned}
& L_{i}=c_{i} \ln h_{i}\left(d_{i}\right)+\sum_{t=1}^{d_{i}-1} \ln \left[1-h_{i}(t)\right]= \\
& c_{i} \ln \left\{1-\exp \left[-\exp \left(x_{i}\left(d_{i}\right)^{\prime} \beta\right) \gamma\left(d_{i}\right)\right]\right\}-\sum_{t=1}^{d_{i}-1} \exp \left(x_{i}(t)^{\prime} \beta\right) \gamma(t)
\end{aligned}
$$

where $c_{i}$ is an indicator variable that equals to 1 if the spell is completed and 0 if it is censored. It is known that stock sampling might lead to sample selection bias as only those who have survived up to the current state are observed. This is referred as left truncation in the literature (see Guo, 1993; Jenkins, 1995) and it is particular relevant in our context since more successful entrepreneurs are more likely to be overrepresented in the stock sample. To take into account this source of bias we modify the likelihood function by conditioning the transition rates on the length of business operation at the first interview date. We are able to do so as the data provide the exact starting date for each particular business. Suppose that an individual $i$ enters the survey $j$ months after having started a business and runs it for another $k_{i}$ months, completing a total duration of $d_{i}=j_{i}+k_{i}$ months in entrepreneurship, that can be either censored or uncensored. The individual likelihood contribution for the left-truncated spells becomes 


$$
\begin{aligned}
& L_{i}=c_{i} \ln h_{i}\left(d_{i}\right)+\sum_{t=j_{i}+1}^{d_{i}-1} \ln \left[1-h_{i}(t)\right]= \\
& c_{i} \ln \left\{1-\exp \left[-\exp \left(x_{i}\left(d_{i}\right)^{\prime} \beta\right) \gamma\left(d_{i}\right)\right]\right\}-\sum_{t=j_{i}+1}^{d_{i}-1} \exp \left(x_{i}(t)^{\prime} \beta\right) \gamma(t)
\end{aligned}
$$

The log-likelihood, which is the sum of these contributions both for the inflow and the stock sample, is maximized with respect to $\beta$ and a full set of $\gamma s$ to provide maximum likelihood estimates.

We extend the above model to take into account competing risks. As Narendranathan and Stewart (1993) showed, if distinct destination states depend upon disjoint subsets of parameters, the parameters of a state-specific hazard can be estimated by treating durations finishing into other states as censored at the time of exit. We focus on the distinction between transitions to paid employment and to non-employment, which includes both unemployment and inactivity. ${ }^{7}$ For each specific transition we treat exit to the other state as censored spells. Therefore, the semi-parametric hazard specification in (4) and (5) used for the single-risk model can be applied for the transitions to employment and to non-employment, respectively.

Finally, we relax the maintained assumption that all heterogeneity is due to observed variables. We assume that unobserved heterogeneity can be represented by the introduction into the hazard function of a stochastic disturbance term $v$, with density function $f_{v}($ ), which is independent of the factors that determine the hazard function. Following a widely used approach of duration analysis in labor economics based on Heckman and Singer (1984), we do not impose a distributional assumption on $v$, which allows the distribution to be asymmetric. The distribution of unobserved heterogeneity $f_{v}()$ is assumed to be discrete with two points of support $p_{1}$ and $p_{2}$, where:

$$
\operatorname{Pr}\left(v=v_{a}\right)=p_{1} \quad \operatorname{Pr}\left(\mathrm{v}=v_{b}\right)=p_{2}=1-p 1
$$

\footnotetext{
${ }^{7}$ Due to sample size limitations we do not distinguish in what follows between unemployment and inactivity.
} 
which is supposed to have a logit specification with $p_{1}=\frac{e^{a_{1}}}{e^{a_{1}}+e^{a_{2}}}$, and $\alpha_{2}$ is set equal to zero for normalization. The unobserved effect is removed by taking expectations

$$
L_{i}=E_{v}\left[L_{i} \mid v_{i}\right]
$$

\section{Empirical Results}

\subsection{Transitions into Entrepreneurship}

We first provide estimates from a logistic regression on the determinants of starting up a business. Although the innovative part of our study is the analysis of the survival into entrepreneurship and of exits to different states, for consistency with the existing literature we also briefly look at the determinants of entry into entrepreneurship and the extent to which they differ among various immigrant groups and the U.S.-born. The sample consists of all the individuals who do not own a business and we estimate the determinants of the probability to enter into entrepreneurship in the following wave. We consider three different specifications with emphasis on the effects of immigrant status. The first allows for a dummy for foreignborn immigrants, where the reference group comprises U.S. born individuals. The second specification distinguishes the foreign-born into four groups (Mexican, other Hispanic, Asian and European). The third specification allows for ethnic group dummies both for the foreignborn and for the U.S.-born descendants of immigrants, so that the reference group comprises non-Hispanic whites. ${ }^{8}$

[Table 2]

\footnotetext{
${ }^{8}$ We include a dummy for African-Americans to distinguish them from the reference group.
} 
Results from Table 2 suggest that there is no significant difference in the entry rates between immigrants and their U.S.-born counterparts. This finding is consistent with existing evidence of no differences in the entry rates among ethnic and racial groups (Fairlie and Meyer 1996, Loftstrom and Wang 2006). In terms of other characteristics, a college degree, being married, higher state unemployment rates, and being previously unemployed or inactive significantly encourage entering into entrepreneurship. The higher entry rate of unemployed and inactive individuals suggests entrepreneurship as a possible way out of non-employment. We investigate further the extent to which this pathway through business ownership is followed by different immigrant and ethnic groups. Table 3 presents estimates for the probability to become an entrepreneur by ethnic group and immigrant status. We observe that Mexicans and other Hispanics, who are not employed, are significantly more likely to start up a business. However, this is not the case for Asians.

\section{[Table 3]}

\subsection{Transitions out of Entrepreneurship}

\subsubsection{Logistic Estimates}

Turning to the analysis of the determinants of the exit probability and the extent to which they differ across immigrant groups, we first perform a static logit analysis that does not impose too much structure in the empirical model. However, logit analysis does not capture duration dependence and does not take into account right censoring and left truncation, which might lead to biased estimates. The probability of exiting within a particular period can be written as: $\operatorname{Pr}\left(t \geq t_{r}\right)=1 /\left(1+e^{x^{\prime} \beta}\right)$ and $\operatorname{Pr}\left(t<t_{r}\right)=\left(e^{x^{\prime} \beta}\right) /\left(1+e^{x^{\prime} \beta}\right)$, where $t$ is the completed duration of business ownership, $t_{r}$ is a threshold (1,2, 3, or 4 years), $x$ is a vector of explanatory variables, and $\beta$ is a vector of unknown parameters to be estimated. 
We provide the full set of estimates for the third specification, which is the most informative one in terms of the ethnic group dummies, providing detailed breakdown for both the immigrants and their U.S.-born descendants. Results summarized by Table 4, suggest that all immigrant groups exhibit a higher exit rate compared to non-Hispanic whites. The effect is not significant for the first year, but it becomes significant from the second year onwards. With regard to the U.S.-born descendants of immigrants, we also observe significant and positive effects for the second and third year for Mexicans and other Hispanics and a negative effect for Asians. ${ }^{9}$ The effects for the other characteristics suggest that older, more educated, married, wealthier, with small business size, and in states with high unemployment rates are less likely to exit from entrepreneurship.

[Table 4]

\subsubsection{Hazard Estimates}

In order to illustrate the importance of taking into account left truncation, we estimate the hazard model outlined in section 4 under two different scenarios. In the first, we ignore the information on the starting date of the business, as if it was not known, while in the second, we condition on the elapsed duration as described in (5) for the left truncated spells. The controls are the ones which are used in the logit analysis, except that we now capture economic wide effects by using a time-varying state unemployment rate in the discrete hazard model, compared to the unemployment rate at the beginning of the spell which is used in the logit model.

The hazard estimates without controlling for left truncation, reported in Table 5, suggest similar results with the logit estimates. According to the specification in column 1 ,

\footnotetext{
${ }^{9}$ The coefficient estimate of the foreign-born dummy in the first specification is 0.867 and significant at the $10 \%$ level. The results of these estimations are available from the authors upon request.
} 
immigrants are significantly more likely to exit from entrepreneurship compared to the U.S.born, while according to the estimates in columns 2 and 3, the effects are significant for each of the immigrant groups we consider.

\section{[Table 5]}

Table 6 reports the hazard estimates when we take into account the bias induced by left truncation. According to the first specification immigrants, are more likely to exit entrepreneurship compared to the reference group of U.S-born individuals (the effect is significant at $10 \%)$. The second specification, presented in the second column, suggests that there are differences in the hazard rates across different immigrant groups. In particular, foreign-born Mexicans and other Hispanics exhibit significantly higher exit rates, while those of Asians and Europeans do not differ significantly from the U.S.-born. These results differ from the estimates that did not condition on the elapsed duration for the left truncated spells, in which all immigrant groups were found to have significantly higher exit rates compared to their U.S.-born counterparts. The above comparison shows how much different results can be obtained when one relies on static logit models that ignore left truncated spells, and it points to an issue that seems to be overlooked by the existing empirical literature on business survival of various racial and ethnic groups.

\section{[Table 6]}

The results from the third specification of Table 6 show that Mexican and other Hispanic immigrants still exhibit higher exit rates from entrepreneurship, when the reference group comprises non-Hispanic whites. However, such differences in survival do not carry on 
to U.S.-born descendants of these two immigrant groups, as they do not exhibit significantly different exit rates relative to the reference group. Finally, among the U.S-born individuals, African-Americans is the only group with a significantly higher exit rate from entrepreneurship, which is in line with existing evidence of low self-employment rates among blacks (Fairlie, 1999).

Regarding the effect of other characteristics, age, education, and being married have a significantly negative effect on the exit rate from entrepreneurship. In particular, an additional year of age lowers the hazard at a decreasing rate, while being a college graduate has the largest negative impact. Wealthier entrepreneurs are also less likely to exit. This effect points on the importance of economic resources and on the relevance of liquidity constraints, that the less well to do are more likely to face, in business survival. Years since immigration suggest also a negative effect for immigrants with more years in the U.S., which gradually becomes smoother. On the other hand, while high unemployment rates at the state level were found to be a pushing factor for starting up a business, they no longer affect the survival into entrepreneurship. Finally, the duration dependence coefficients show a non-linear effect of the elapsed time in entrepreneurship on the exit rate. The hazard rate is increasing at the beginning of the spells and declines as the spells last longer.

\subsubsection{Competing Risk Model}

Having showed a higher exit rate from entrepreneurship for Mexican and other Hispanic immigrants, we go a step further in our analysis by investigating the nature of these transitions. Based on the logit estimates for entry, we have seen that unemployed and inactive individuals are more likely to enter into entrepreneurship suggesting non-employment as a pushing factor, which was found to be more prevalent for Mexicans and other Hispanics. We 
extend our hazard model into a competing risk framework where we consider transitions from business to either employment or non-employment, as described in section $4 .^{10}$

Table 7 reports the coefficient estimates for the two risks. It shows that the higher exit rate of immigrants from entrepreneurship is directed towards paid-employment and not towards non-employment. The coefficient for the foreign-born dummy, in the first column for the exit to paid-employment, is positive and statistically significant. However, it is not significant for the exit to non-employment (column 4). In addition, columns 2 and 3 show that Mexican and other Hispanic immigrants are also more likely to make a transition out of entrepreneurship to paid-employment. Interestingly, the opposite holds for AfricanAmericans. Based on the estimates of column 6, African-Americans are significantly more likely to exit from entrepreneurship to non-employment.

[Table 7]

\subsection{Sensitivity Analysis}

We investigate the sensitivity of our results to the presence of unobserved heterogeneity applying the method by Heckman and Singer (1984), as describe in section 4. For all the three specifications unobserved heterogeneity was not found to be significant.

\section{[Table 8]}

We also evaluate the sensitivity of our main results with respect to the way duration dependence is specified. So far, we have allowed a flexible specification for duration

\footnotetext{
${ }^{10}$ Controlling for past labor market status in the hazard model is not possible as we do not have this information for the left truncated spells. That is, the spells for business that started before the first available wave in 1996. In the entry model this information is available as the sample which is used is conditioned on being either into paidemployment or non-employment. Focusing only on the inflow sample (the fresh spells) reduces the sample size so dramatically that any similar analysis is not feasible.
} 
dependence based on the piece-wise exponential form which was common for all groups. Since the effect of time on entrepreneurship might differ between immigrants and the U.S.born, we allow for specific-group duration dependence. Table 8 summarizes the estimates for the immigrant group dummies and the group-specific duration dependence dummies, which is comparable to column 3 of Table 6. We have now defined 12-month intervals dummies (instead of 6-month) in order to facilitate an adequate number of observations in each cell. Allowing for group-specific duration dependence does not affect our main findings for the two foreign-born immigrant groups (Mexican and other Hispanic) and for African-Americans, while again no effect was found for the U.S-born descendants of immigrants. The only difference observed is a slightly lower effect for the foreign-born, which makes the coefficient estimates significant at the $10 \%$ per cent level. ${ }^{11}$ Interestingly, capturing the spikes of the hazard for the U.S.-born immigrants which were shown in Figure 1, we also observe lower coefficients for this group. Finally, allowing for group-specific unobserved heterogeneity it turned out, once again, not to be significant.

\subsection{Simulations}

Using the coefficient estimates of Table 6 (third column), we simulate the survival function for different ethnic groups keeping other characteristics at their mean values. The left panel of Figure 3 shows the simulated survival function of foreign-born immigrants by origin. Mexicans and other Hispanics have the lowest survival probabilities in entrepreneurship. After 2 years (24 months) about 55 per cent of the entrepreneurs in these two groups still survived in business, while the corresponding figure for European foreign-born immigrants is close to 60, and for Asians close to 70 per cent. The right panel of Figure 3 depicts the simulated survival function of U.S.-born descendants by ethnic origin. We observe that the differences across groups are less pronounced especially during the first year of survival.

\footnotetext{
${ }^{11}$ The coefficients of the other variables are not reported as they are similar to those in Table 6.
} 
Moreover, the survival functions for the U.S-born descendants are shifted upwards compared to the foreign-born, so that at a given duration there is a higher survival rate.

\section{[Figure 3]}

\section{Conclusions}

This paper investigates the survival dynamics in entrepreneurship among immigrant groups to the U.S. and their descendants. We adopt a modeling framework based on duration analysis, which is more appropriate in the current context compared to the broadly used static discrete choice models. We do so by utilizing information available in the SIPP on the date of starting up a business, which allows us to construct the exact survival duration into entrepreneurship. Our estimation takes into account the fact that the stock of entrepreneurs initially observed represents a selected sample (left-truncated) of those successful enough to survive up to that point. We show that ignoring such a selection mechanism can have an important effect on the estimation results.

We find a lower survival probability in entrepreneurship for foreign-born individuals compared to non-Hispanic whites, which is due to the higher exit rates for Mexicans and other Hispanics. However, such differences in survival do not carry on to the U.S.-born descendants of these two immigrant groups. Investigating further these transitions, we find that Mexican and other Hispanic immigrants tend to enter entrepreneurship from unemployment or inactivity, and they are more likely to exit towards employment in the wage sector. However, African-Americans who also exhibit a lower survival in entrepreneurship, show a higher propensity to exit to non-employment.

These results contribute to our further understanding of the observed differences in selfemployment rates among racial and ethnic groups. For Mexicans and other Hispanics, 
entrepreneurship is more likely to represent an intermediate step from non-employment to paid employment, which is not the case for African-Americans. Exploring differences in wages and well-being that such transitions imply are left for future research. 


\section{References}

Borjas, G.J. (1993): "The Intergenerational Mobility of Immigrants", Journal of Labor Economics, 11(1), pp. 113-115.

Chiswick, B.R. (1977): "Sons of Immigrants: Are They at and Earnings Disadvantage?" American Economic Review, Papers and Proceedings, 67, pp. 376-380.

Cobb-Clark D.A and V.A.Hildebrand (2006): "The Wealth and Asset Holdings of U.S.-Born and Foreign-Born Households: Evidence from SIPP Data", Review of Income and Wealth, 52(1), pp. 17-42.

Evans, D. and B. Jovanovic (1989): "An Estimated Model of Entrepreneurial Choice Under Liquidity Constraints", Journal of Political Economy, 97(4), pp. 808-27.

Evans, D. and L. Leighton (1989): "Some Empirical Aspects of Entrepreneurship", American Economic Review, 79, pp. 519-535.

Fairlie, R.W and B.D. Meyer (1996): "Ethnic and Racial Self-Employment Differences and Possible Explanations", Journal of Human Resources, 31, pp. 757-793.

Fairlie, R.W. (1999): "The Absence of the African-American Owned Business: An Analysis of the Dynamics of Self-Employment", Journal of Labor Economics, 17(1), pp. 80108.

(2004): "Earnings Growth among Less-Educated Business Owners", Industrial Relations, 43 (3), pp. 634-659.

- (2005): "Entrepreneurship among Disadvantaged Groups: An Analysis of the Dynamics of Self-Employment by Gender, Race, and Education", Handbook of Entrepreneurship, Volume 2, eds. Simon C. Parker, Zoltan J. Acs, and David R. Audretsch, Kluwer Academic Publishers (forthcoming)

Gentry, W.M. and G. Hubbard (2004): "Success Taxes, Entrepreneurial Entry, and Innovation", NBER Working Papers No. 10551.

Heckman, J.J. and B. Singer (1984): "A Method for Minimizing the Distributional Assumptions in Econometric Models for Duration Data", Econometrica, 52, pp. 271320.

Hotz-Eakin, D., H.S. Rosen and R. Weathers (2000): "Horatio Alger Meets the Mobility Tables", Small Business Economics, 14, pp. 243-274.

Hout, M. and H.S. Rosen (2000): "Self-Employment, Family Background, and Race", Journal of Human Resources, 35(4), pp. 670-92. 
Hurst, E. and A. Lusardi (2004): "Liquidity Constraints, Household Wealth, and Entrepreneurship", Journal of Political Economy, 112(2), pp. 319-347.

Jenkins, S. (1995): "Easy Estimation Methods for Discrete Time Duration Models", Oxford Bulletin of Economics and Statistics, 57 (1), 129 - 137.

Lofstrom, M. and C. Wang (2006): "Hispanic Self-Employment: A Dynamic Analysis of Business Ownership", IZA Discussion Paper No. 2101.

Narendranathan, W. and M. Stewart (1993): "Modelling the Probability of Leaving Unemployment: Competing Risks Models with Flexible Base-line Hazards", Applied Statistics, 42, $63-83$.

Quadrini, V. (1999): "The Importance of Entrepreneurship for Wealth Concentration and Mobility", Review of Income and Wealth, 45(1).

Trejo, S.J. (2003): "Intergenerational Progress of Mexican-Origin Workers in the U.S. Labor Market" Journal of Human Resources, 38(3), pp. 467-489. 


\section{Figure 1. Empirical Hazard Estimates}


C. Foreign-Born by Ethnicity
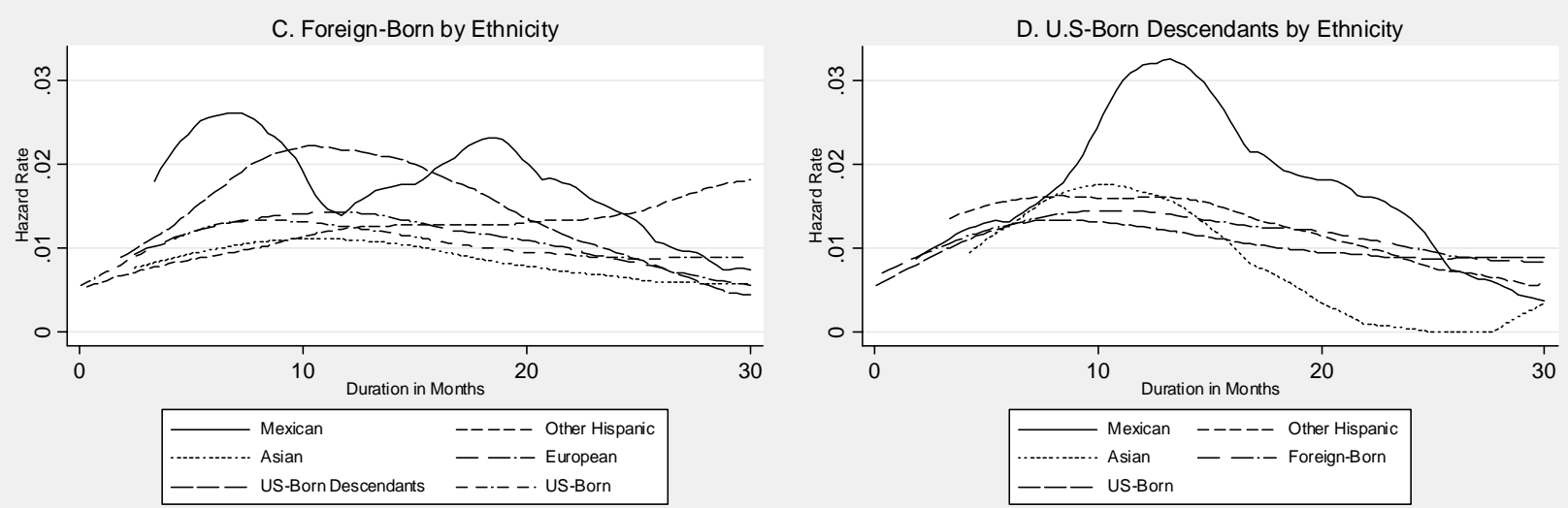


\section{Figure 2. Empirical Survival Function}
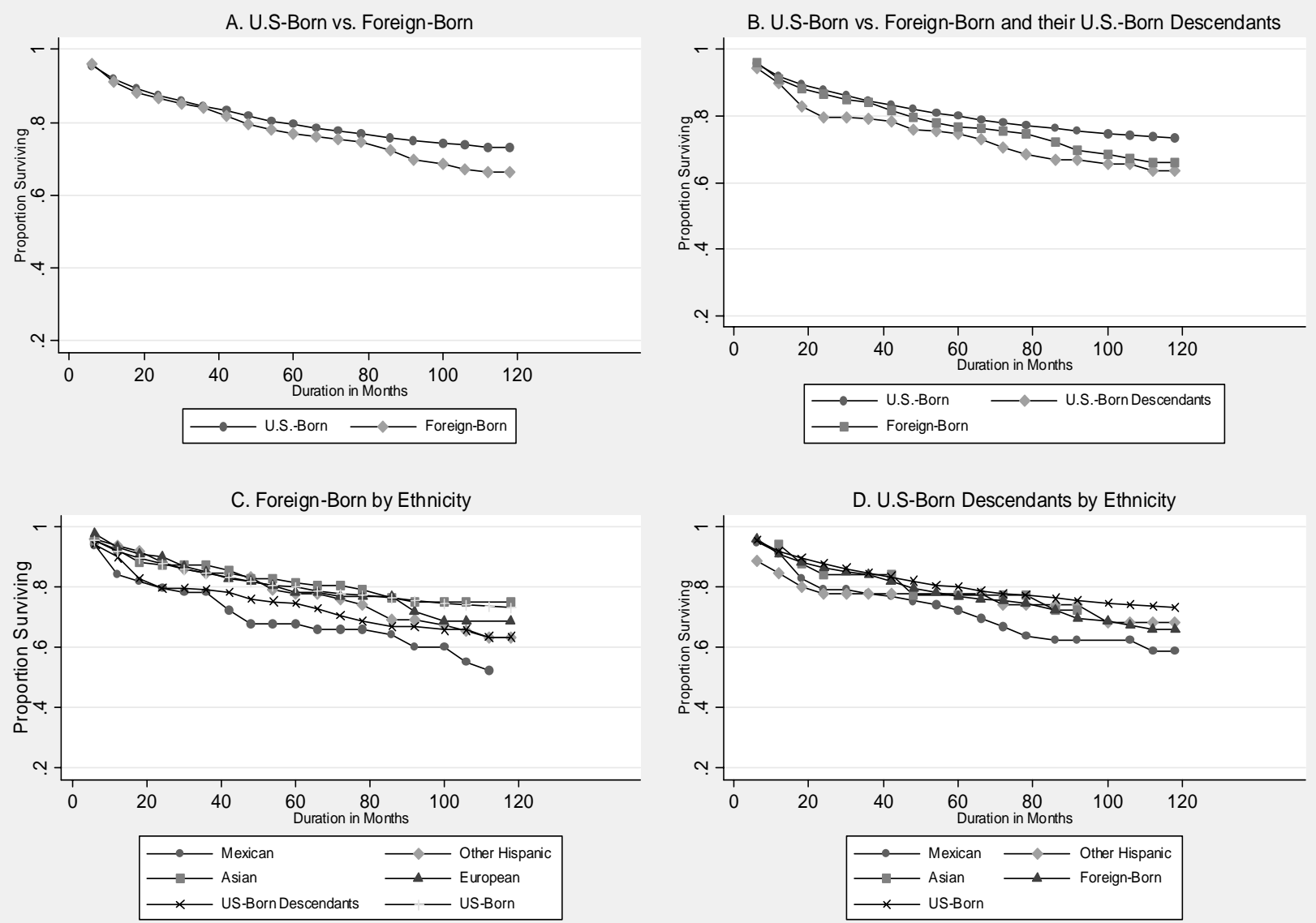


\section{Figure 3. Simulated Survival Function by Ethnic Groups}
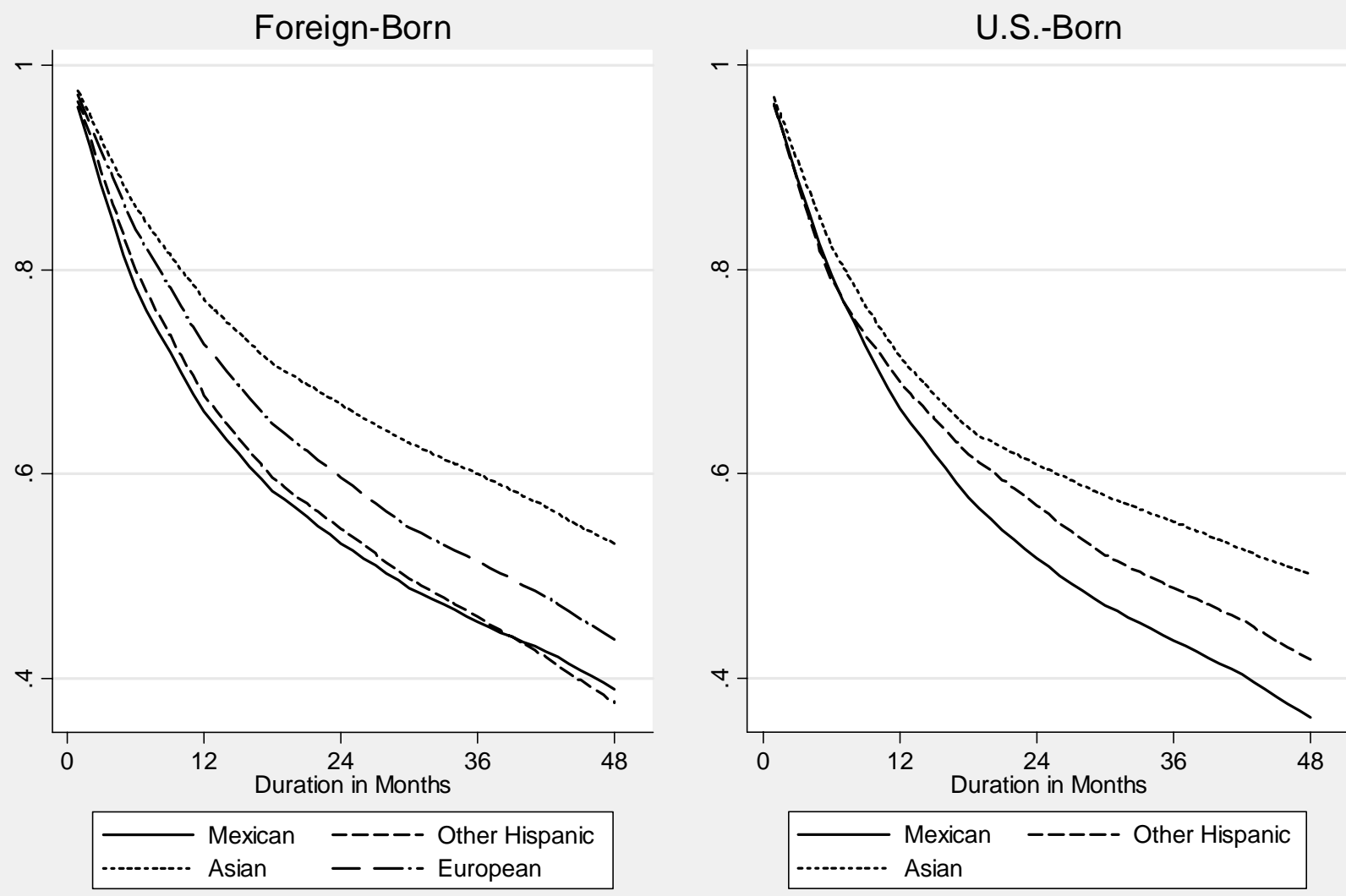


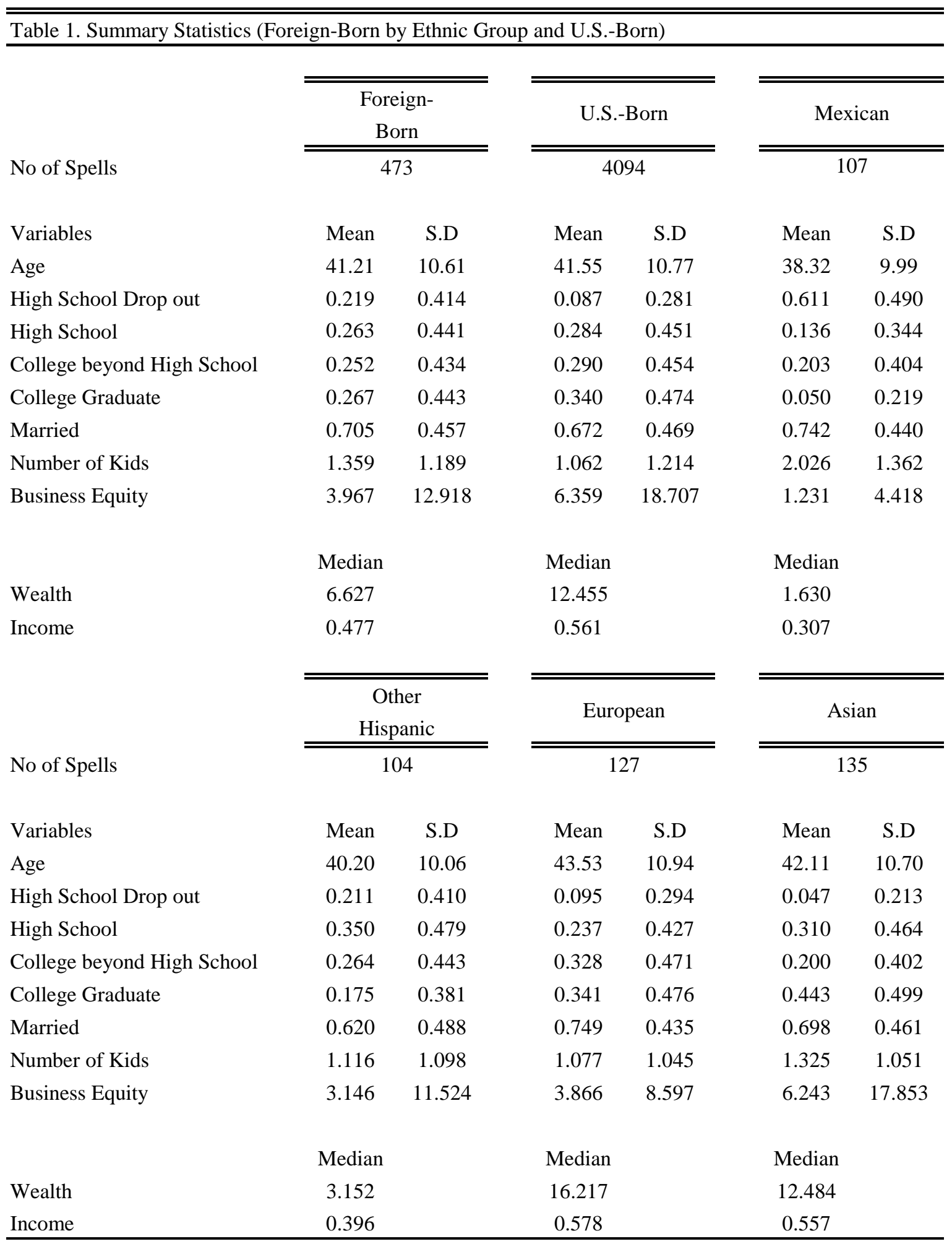

Source: SIPP 1996. Wealth, Income and Business Equity are measured in 10,000's dollars in 1996 prices. Statistics are adjusted by the use of survey weights. 


\begin{tabular}{|c|c|c|c|}
\hline Foreign-Born & $\begin{array}{c}0.194 \\
(0.172)\end{array}$ & & \\
\hline Mexican & & $\begin{array}{c}0.174 \\
(0.233)\end{array}$ & $\begin{array}{c}0.159 \\
(0.233)\end{array}$ \\
\hline Other Hispanic & & $\begin{array}{c}0.079 \\
(0.221)\end{array}$ & $\begin{array}{c}0.066 \\
(0.222)\end{array}$ \\
\hline Asian & & $\begin{array}{c}0.269 \\
(0.213)\end{array}$ & $\begin{array}{c}0.258 \\
(0.213)\end{array}$ \\
\hline European & & $\begin{array}{c}0.277 \\
(0.212)\end{array}$ & $\begin{array}{c}0.269 \\
(0.212)\end{array}$ \\
\hline \multicolumn{4}{|l|}{ U.S.-Born } \\
\hline Mexican & & & $\begin{array}{c}-0.136 \\
(0.123)\end{array}$ \\
\hline Other Hispanic & & & $\begin{array}{c}0.118 \\
(0.155)\end{array}$ \\
\hline Asian & & & $\begin{array}{c}-0.098 \\
(0.242)\end{array}$ \\
\hline African American & & & $\begin{array}{c}-0.118 \\
(0.084)\end{array}$ \\
\hline Years since Immigration & $\begin{array}{l}-0.017 \\
(0.022)\end{array}$ & $\begin{array}{c}-0.015 \\
(0.024)\end{array}$ & $\begin{array}{c}-0.016 \\
(0.024)\end{array}$ \\
\hline Years since Immigration^^2/100 & $\begin{array}{c}0.049 \\
(0.058)\end{array}$ & $\begin{array}{c}0.041 \\
(0.064)\end{array}$ & $\begin{array}{c}0.043 \\
(0.064)\end{array}$ \\
\hline Age & $\begin{array}{c}0.135^{* * * *} \\
(0.014)\end{array}$ & $\begin{array}{c}0.136 * * * \\
(0.014)\end{array}$ & $\begin{array}{c}0.136^{* * *} \\
(0.014)\end{array}$ \\
\hline Age $^{\wedge} 2 / 100$ & $\begin{array}{c}-0.002 * * * \\
0.000\end{array}$ & $\begin{array}{c}-0.002^{* * *} \\
0.000\end{array}$ & $\begin{array}{c}-0.002 * * * \\
0.000\end{array}$ \\
\hline High School & $\begin{array}{c}0.007 \\
(0.078)\end{array}$ & $\begin{array}{c}-0.002 \\
(0.080)\end{array}$ & $\begin{array}{c}-0.001 \\
(0.080)\end{array}$ \\
\hline College beyond High School & $\begin{array}{c}0.103 \\
(0.078)\end{array}$ & $\begin{array}{c}0.092 \\
(0.081)\end{array}$ & $\begin{array}{c}0.092 \\
(0.081)\end{array}$ \\
\hline College Graduate & $\begin{array}{c}0.276^{* * * *} \\
(0.078)\end{array}$ & $\begin{array}{c}0.262 * * * \\
(0.081)\end{array}$ & $\begin{array}{c}0.254^{* * *} \\
(0.082)\end{array}$ \\
\hline Married & $\begin{array}{c}0.176^{* * *} \\
(0.055)\end{array}$ & $\begin{array}{c}0.177^{* * *} \\
(0.055)\end{array}$ & $\begin{array}{c}0.170^{* * *} \\
(0.055)\end{array}$ \\
\hline Number of Kids & $\begin{array}{c}-0.122 * * * \\
(0.020)\end{array}$ & $\begin{array}{c}-0.123 * * * \\
(0.020)\end{array}$ & $\begin{array}{c}-0.121 * * * \\
(0.020)\end{array}$ \\
\hline HH Wealth & $\begin{array}{c}-0.002 \\
(0.003)\end{array}$ & $\begin{array}{l}-0.002 \\
(0.003)\end{array}$ & $\begin{array}{c}-0.002 \\
(0.003)\end{array}$ \\
\hline HH Income & $\begin{array}{c}-0.093^{* * *} \\
(0.012)\end{array}$ & $\begin{array}{c}-0.093 * * * \\
(0.012)\end{array}$ & $\begin{array}{c}-0.093^{* * *} \\
(0.012)\end{array}$ \\
\hline State Unemployment Rate & $\begin{array}{c}0.095^{* * *} \\
(0.017)\end{array}$ & $\begin{array}{c}0.095^{* * *} \\
(0.017)\end{array}$ & $\begin{array}{c}0.097 * * * \\
(0.017)\end{array}$ \\
\hline Urban Resident & $\begin{array}{l}-0.013 \\
(0.045)\end{array}$ & $\begin{array}{c}-0.011 \\
(0.045)\end{array}$ & $\begin{array}{c}-0.007 \\
(0.046)\end{array}$ \\
\hline Previously Unemployed & $\begin{array}{c}0.971^{* * *} \\
(0.089)\end{array}$ & $\begin{array}{c}0.973^{* * *} \\
(0.089)\end{array}$ & $\begin{array}{c}0.980 * * * \\
(0.089)\end{array}$ \\
\hline Previously Inactive & $\begin{array}{c}0.494^{* * *} \\
(0.069)\end{array}$ & $\begin{array}{c}0.491^{* * *} \\
(0.069)\end{array}$ & $\begin{array}{c}0.496 * * * \\
(0.070)\end{array}$ \\
\hline Constant & $\begin{array}{c}-6.951 * * * \\
(0.312)\end{array}$ & $\begin{array}{c}-6.951 * * * \\
(0.312)\end{array}$ & $\begin{array}{c}-6.958 * * * \\
(0.312)\end{array}$ \\
\hline Observations & 175229 & 175229 & 175229 \\
\hline
\end{tabular}

Notes: Robust standard errors in parentheses. * significant at $10 \%$; ** significant at $5 \%$; *** significant at $1 \%$. The sample consists of all individuals who do not own a business and the dependent variable takes the value 1 for those who start up a business in the following wave. Year dummies are included in each specification. 


\begin{tabular}{|c|c|c|c|c|}
\hline & Mexican & Other Hispanic & Asian & European \\
\hline Foreign-Born & $\begin{array}{c}0.998 * * \\
(0.434)\end{array}$ & $\begin{array}{c}0.116 \\
(0.372)\end{array}$ & $\begin{array}{c}0.264 \\
(0.389)\end{array}$ & \\
\hline Years since Immigration & $\begin{array}{c}-0.114^{* *} \\
(0.051)\end{array}$ & $\begin{array}{c}-0.053 \\
(0.056)\end{array}$ & $\begin{array}{c}-0.007 \\
(0.047)\end{array}$ & $\begin{array}{c}-0.015 \\
(0.060)\end{array}$ \\
\hline Years since Immigration^^2/100 & $\begin{array}{c}0.264^{*} \\
(0.136)\end{array}$ & $\begin{array}{c}0.201 \\
(0.177)\end{array}$ & $\begin{array}{c}0.029 \\
(0.125)\end{array}$ & $\begin{array}{c}0.046 \\
(0.143)\end{array}$ \\
\hline Age & $\begin{array}{l}0.114^{*} \\
(0.060)\end{array}$ & $\begin{array}{c}0.298 * * * \\
(0.094)\end{array}$ & $\begin{array}{c}0.076 \\
(0.068)\end{array}$ & $\begin{array}{c}0.169 \\
(0.106)\end{array}$ \\
\hline $\operatorname{Age}^{\wedge} 2 / 100$ & $\begin{array}{c}-0.001^{* *} \\
(0.001)\end{array}$ & $\begin{array}{c}-0.004^{* * *} \\
(0.001)\end{array}$ & $\begin{array}{c}-0.001 \\
(0.001)\end{array}$ & $\begin{array}{l}-0.002 * \\
(0.001)\end{array}$ \\
\hline High School & $\begin{array}{c}-0.089 \\
(0.215)\end{array}$ & $\begin{array}{c}0.053 \\
(0.308)\end{array}$ & $\begin{array}{c}-0.327 \\
(0.589)\end{array}$ & $\begin{array}{c}0.480 \\
(0.592)\end{array}$ \\
\hline College beyond High School & $\begin{array}{c}-0.177 \\
(0.243)\end{array}$ & $\begin{array}{c}0.333 \\
(0.321)\end{array}$ & $\begin{array}{c}-0.733 \\
(0.601)\end{array}$ & $\begin{array}{l}1.057 * \\
(0.583)\end{array}$ \\
\hline College Graduate & $\begin{array}{c}0.483 \\
(0.371)\end{array}$ & $\begin{array}{c}0.316 \\
(0.309)\end{array}$ & $\begin{array}{l}-0.490 \\
(0.575)\end{array}$ & $\begin{array}{c}0.118 \\
(0.588)\end{array}$ \\
\hline Married & $\begin{array}{c}0.489 * * \\
(0.220)\end{array}$ & $\begin{array}{c}-0.003 \\
(0.284)\end{array}$ & $\begin{array}{c}0.240 \\
(0.297)\end{array}$ & $\begin{array}{c}0.420 \\
(0.334)\end{array}$ \\
\hline Number of Kids & $\begin{array}{c}-0.053 \\
(0.052)\end{array}$ & $\begin{array}{c}-0.028 \\
(0.105)\end{array}$ & $\begin{array}{l}-0.174 * \\
(0.095)\end{array}$ & $\begin{array}{l}-0.212^{*} \\
(0.120)\end{array}$ \\
\hline HH Wealth & $\begin{array}{c}0.001 \\
(0.010)\end{array}$ & $\begin{array}{c}0.017 \\
(0.014)\end{array}$ & $\begin{array}{c}0.001 \\
(0.016)\end{array}$ & $\begin{array}{c}0.029 \\
(0.022)\end{array}$ \\
\hline HH Income & $\begin{array}{c}-0.130 * * * \\
(0.040)\end{array}$ & $\begin{array}{c}-0.093^{* *} \\
(0.037)\end{array}$ & $\begin{array}{l}-0.075 \\
(0.088)\end{array}$ & $\begin{array}{c}-0.081 \\
(0.083)\end{array}$ \\
\hline State Unemployment Rate & $\begin{array}{c}0.054 \\
(0.082)\end{array}$ & $\begin{array}{c}0.026 \\
(0.098)\end{array}$ & $\begin{array}{c}0.063 \\
(0.106)\end{array}$ & $\begin{array}{c}0.158 \\
(0.146)\end{array}$ \\
\hline Urban Resident & $\begin{array}{c}-0.148 \\
(0.192)\end{array}$ & $\begin{array}{l}-0.305 \\
(0.243)\end{array}$ & $\begin{array}{l}-0.014 \\
(0.315)\end{array}$ & $\begin{array}{c}0.049 \\
(0.351)\end{array}$ \\
\hline Previously Unemployed & $\begin{array}{c}0.929 * * * \\
(0.296)\end{array}$ & $\begin{array}{c}1.685^{* * *} \\
(0.270)\end{array}$ & $\begin{array}{c}0.548 \\
(0.430)\end{array}$ & $\begin{array}{c}0.793 \\
(0.690)\end{array}$ \\
\hline Previously Inactive & $\begin{array}{c}0.778^{* * *} \\
(0.250)\end{array}$ & $\begin{array}{c}1.091^{* * *} \\
(0.318)\end{array}$ & $\begin{array}{c}-0.611 \\
(0.461)\end{array}$ & $\begin{array}{c}0.206 \\
(0.391)\end{array}$ \\
\hline Constant & $\begin{array}{c}-6.034 * * * \\
(1.162)\end{array}$ & $\begin{array}{c}-9.749 * * * \\
(1.871)\end{array}$ & $\begin{array}{c}-5.417 * * * \\
(1.629)\end{array}$ & $\begin{array}{c}-7.900 * * * \\
(2.188)\end{array}$ \\
\hline Observations & 12116 & 6565 & 5379 & 3510 \\
\hline
\end{tabular}




$\leq 1$ year $\quad \leq 2$ year $\quad \leq$ 3year $\leq 4$ year

\section{Foreign-Born}

\begin{tabular}{|c|c|c|c|c|}
\hline Mexican & $\begin{array}{c}0.835 \\
(0.545)\end{array}$ & $\begin{array}{c}0.784 \\
(0.554)\end{array}$ & $\begin{array}{c}0.754 \\
(0.542)\end{array}$ & $\begin{array}{l}1.022 * * \\
(0.510)\end{array}$ \\
\hline \multirow{2}{*}{ Other Hispanic } & 0.570 & $0.922^{*}$ & 0.580 & 0.431 \\
\hline & $(0.588)$ & $(0.512)$ & $(0.508)$ & $(0.490)$ \\
\hline \multirow[t]{2}{*}{ Asian } & 0.794 & $0.858 *$ & 0.535 & $0.776^{*}$ \\
\hline & $(0.513)$ & $(0.497)$ & $(0.489)$ & $(0.463)$ \\
\hline \multirow[t]{2}{*}{ European } & 0.869 & $1.242 * *$ & $1.131^{* *}$ & $1.221^{* *}$ \\
\hline & $(0.544)$ & $(0.524)$ & $(0.535)$ & $(0.484)$ \\
\hline \multicolumn{5}{|l|}{ U.S.-Born } \\
\hline \multirow[t]{2}{*}{ Mexican } & 0.019 & $0.642 * *$ & $0.470 *$ & 0.291 \\
\hline & $(0.319)$ & $(0.280)$ & $(0.262)$ & $(0.251)$ \\
\hline \multirow[t]{2}{*}{ Other Hispanic } & 0.432 & $0.766 * *$ & $0.720 * *$ & 0.309 \\
\hline & $(0.342)$ & $(0.315)$ & $(0.330)$ & $(0.320)$ \\
\hline \multirow[t]{2}{*}{ Asian } & -1.273 & -0.210 & $-0.981^{* *}$ & -0.487 \\
\hline & $(0.808)$ & $(0.476)$ & $(0.473)$ & $(0.484)$ \\
\hline \multirow[t]{2}{*}{ African American } & -0.205 & 0.031 & 0.183 & 0.172 \\
\hline & $(0.228)$ & $(0.205)$ & $(0.188)$ & $(0.180)$ \\
\hline \multirow[t]{2}{*}{ Years since Immigration } & -0.066 & -0.063 & -0.028 & -0.048 \\
\hline & $(0.057)$ & $(0.052)$ & $(0.049)$ & $(0.048)$ \\
\hline \multirow[t]{2}{*}{ Years since Immigration $` 2 / 100$} & 0.109 & 0.099 & -0.002 & 0.066 \\
\hline & $(0.146)$ & $(0.129)$ & $(0.118)$ & $(0.117)$ \\
\hline \multirow[t]{2}{*}{ Age } & $-0.161^{* * *}$ & $-0.182 * * *$ & $-0.180 * * *$ & $-0.190 * * *$ \\
\hline & $(0.033)$ & $(0.030)$ & $(0.029)$ & $(0.028)$ \\
\hline \multirow[t]{2}{*}{$\operatorname{Age}^{\wedge} 2 / 100$} & $0.153 * * *$ & $0.161^{* * *}$ & $0.154 * * *$ & $0.156^{* * *}$ \\
\hline & $(0.040)$ & $(0.036)$ & $(0.035)$ & $(0.033)$ \\
\hline \multirow[t]{2}{*}{ High School } & $-0.396 * *$ & $-0.336 * *$ & -0.230 & -0.228 \\
\hline & $(0.168)$ & $(0.155)$ & $(0.146)$ & $(0.140)$ \\
\hline \multirow[t]{2}{*}{ College beyond High School } & -0.268 & -0.167 & -0.179 & -0.129 \\
\hline & $(0.169)$ & $(0.155)$ & $(0.145)$ & $(0.140)$ \\
\hline \multirow[t]{2}{*}{ College Graduate } & $-0.642 * * *$ & $-0.335 *$ & $-0.274^{*}$ & $-0.275^{*}$ \\
\hline & $(0.189)$ & $(0.171)$ & $(0.160)$ & $(0.151)$ \\
\hline \multirow[t]{2}{*}{ Married } & $-0.396 * * *$ & $-0.279 * * *$ & $-0.348 * * *$ & $-0.270 * * *$ \\
\hline & $(0.116)$ & $(0.105)$ & $(0.099)$ & $(0.093)$ \\
\hline \multirow[t]{2}{*}{ Number of Kids } & -0.019 & -0.055 & -0.051 & $-0.064 *$ \\
\hline & $(0.045)$ & $(0.039)$ & $(0.037)$ & $(0.034)$ \\
\hline \multirow[t]{2}{*}{ HH Wealth } & $-0.019 * * *$ & $-0.018 * * *$ & $-0.022 * * *$ & $-0.024 * * *$ \\
\hline & $(0.006)$ & $(0.006)$ & $(0.005)$ & $(0.005)$ \\
\hline \multirow[t]{2}{*}{ HH Income } & $-0.104^{* * *}$ & $-0.115^{* * *}$ & $-0.114^{* * *}$ & $-0.122 * * *$ \\
\hline & $(0.027)$ & $(0.027)$ & $(0.027)$ & $(0.025)$ \\
\hline \multirow[t]{2}{*}{ Agriculture } & $-0.323 *$ & $-0.358 * *$ & $-0.369 * *$ & $-0.438 * * *$ \\
\hline & $(0.181)$ & $(0.169)$ & $(0.160)$ & $(0.147)$ \\
\hline \multirow[t]{2}{*}{ Manufacturing Durables } & -0.108 & 0.239 & $0.506^{*}$ & 0.313 \\
\hline & $(0.424)$ & $(0.338)$ & $(0.307)$ & $(0.287)$ \\
\hline \multirow[t]{2}{*}{ Manufacturing Non-Durables } & 0.062 & 0.115 & -0.013 & 0.129 \\
\hline & $(0.273)$ & $(0.235)$ & $(0.234)$ & $(0.214)$ \\
\hline Transportation & 0.193 & 0.303 & $0.468 * *$ & $0.519 * * *$ \\
\hline & $(0.207)$ & $(0.188)$ & $(0.183)$ & $(0.175)$ \\
\hline Trade Durables & $-0.605^{*}$ & -0.272 & -0.090 & 0.205 \\
\hline & $(0.363)$ & $(0.301)$ & $(0.272)$ & $(0.240)$ \\
\hline
\end{tabular}




\begin{tabular}{lcccc} 
Trade Non-Durables & -0.492 & 0.023 & 0.343 & 0.431 \\
Retail & $(0.460)$ & $(0.346)$ & $(0.308)$ & $(0.271)$ \\
& -0.191 & 0.090 & $0.279^{*}$ & $0.341^{* *}$ \\
Financial Services & $(0.205)$ & $(0.163)$ & $(0.149)$ & $(0.141)$ \\
& -0.175 & 0.050 & 0.322 & $0.520^{* * *}$ \\
Business Services & $(0.275)$ & $(0.230)$ & $(0.208)$ & $(0.187)$ \\
& -0.098 & 0.098 & $0.273^{* *}$ & $0.256^{* *}$ \\
Personal Services & $(0.159)$ & $(0.141)$ & $(0.133)$ & $(0.127)$ \\
& -0.474 & $-0.562^{* *}$ & -0.225 & -0.299 \\
Entertainment Services & $(0.319)$ & $(0.284)$ & $(0.247)$ & $(0.223)$ \\
& $-0.472^{*}$ & $-0.482^{* *}$ & $-0.421^{*}$ & -0.318 \\
Professional Services & $(0.274)$ & $(0.242)$ & $(0.230)$ & $(0.221)$ \\
Size of Business (1-25 Employees) & 0.077 & 0.110 & 0.221 & $0.386^{* * *}$ \\
Size of Business (25-99 Employees) & $(0.186)$ & $(0.165)$ & $(0.155)$ & $(0.146)$ \\
State Unemployment Rate & $-0.091^{* *}$ & $-0.134^{* * *}$ & $-0.138^{* * *}$ & $-0.124^{* * *}$ \\
& $(0.041)$ & $(0.034)$ & $(0.031)$ & $(0.028)$ \\
Urban Resident & $0.195^{*}$ & 0.075 & $0.148^{*}$ & $0.191^{* *}$ \\
Constant & $(0.104)$ & $(0.093)$ & $(0.086)$ & $(0.080)$ \\
Observations & $-1.029 * * *$ & $-0.865 * * *$ & $-0.718^{* * *}$ & $-0.694^{* * *}$ \\
\hline
\end{tabular}

Robust standard errors in parentheses. * significant at 10\%; ** significant at 5\%;*** significant at $1 \%$. The sample consists of all existing business spells and the dependent variable takes the value of 1 if there is an exit in the period defined in each column. Year dummies are included in each specification. 


\begin{tabular}{|c|c|c|c|}
\hline & $(1)$ & $(2)$ & $(3)$ \\
\hline Foreign-Born & $\begin{array}{c}0.738 * * * \\
(0.270)\end{array}$ & & \\
\hline Mexican & & $\begin{array}{c}0.907 * * * \\
(0.288)\end{array}$ & $\begin{array}{c}0.959 * * * \\
(0.288)\end{array}$ \\
\hline Other Hispanic & & $\begin{array}{c}0.823^{* *} \\
(0.331)\end{array}$ & $\begin{array}{c}0.860 * * * \\
(0.331)\end{array}$ \\
\hline Asian & & $\begin{array}{l}0.797 * * \\
(0.351)\end{array}$ & $\begin{array}{c}0.856 * * * \\
(0.310)\end{array}$ \\
\hline European & & $\begin{array}{c}0.826 * * * \\
(0.310)\end{array}$ & $\begin{array}{c}0.828 * * \\
(0.351)\end{array}$ \\
\hline \multicolumn{4}{|l|}{ U.S.-Born } \\
\hline Mexican & & & $\begin{array}{c}0.252 \\
(0.186)\end{array}$ \\
\hline Other Hispanic & & & $\begin{array}{c}0.159 \\
(0.247)\end{array}$ \\
\hline Asian & & & $\begin{array}{l}-0.149 \\
(0.315)\end{array}$ \\
\hline African American & & & $\begin{array}{c}0.254^{* *} \\
(0.111)\end{array}$ \\
\hline Years since Immigration & $\begin{array}{c}-0.076 * * \\
(0.032)\end{array}$ & $\begin{array}{c}-0.086^{* *} \\
(0.035)\end{array}$ & $\begin{array}{c}-0.085^{* *} \\
(0.035)\end{array}$ \\
\hline Years since Immigration^^2/100 & $\begin{array}{l}0.180 * * \\
(0.079)\end{array}$ & $\begin{array}{l}0.202 * * \\
(0.089)\end{array}$ & $\begin{array}{c}0.201 * * \\
(0.089)\end{array}$ \\
\hline Age & $\begin{array}{c}-0.173^{* * *} \\
(0.018)\end{array}$ & $\begin{array}{c}-0.172 * * * \\
(0.018)\end{array}$ & $\begin{array}{c}-0.174^{* * *} \\
(0.018)\end{array}$ \\
\hline $\operatorname{Age}^{\wedge} 2 / 100$ & $\begin{array}{c}0.159 * * * \\
(0.021)\end{array}$ & $\begin{array}{c}0.158 * * * \\
(0.021)\end{array}$ & $\begin{array}{c}0.159 * * * \\
(0.022)\end{array}$ \\
\hline High School & $\begin{array}{c}-0.207 * * \\
(0.094)\end{array}$ & $\begin{array}{c}-0.193^{* *} \\
(0.096)\end{array}$ & $\begin{array}{l}-0.188 * \\
(0.097)\end{array}$ \\
\hline College beyond High School & $\begin{array}{c}-0.116 \\
(0.095)\end{array}$ & $\begin{array}{c}-0.103 \\
(0.097)\end{array}$ & $\begin{array}{l}-0.086 \\
(0.097)\end{array}$ \\
\hline College Graduate & $\begin{array}{c}-0.220 * * \\
(0.105)\end{array}$ & $\begin{array}{l}-0.207^{*} \\
(0.107)\end{array}$ & $\begin{array}{c}-0.184 * \\
(0.107)\end{array}$ \\
\hline Married & $\begin{array}{c}-0.147 * * \\
(0.067)\end{array}$ & $\begin{array}{c}-0.147^{* *} \\
(0.067)\end{array}$ & $\begin{array}{l}-0.128 * \\
(0.067)\end{array}$ \\
\hline Number of Kids & $\begin{array}{c}-0.018 \\
(0.024)\end{array}$ & $\begin{array}{c}-0.020 \\
(0.025)\end{array}$ & $\begin{array}{l}-0.025 \\
(0.025)\end{array}$ \\
\hline HH Wealth & $\begin{array}{c}-0.015^{* * *} \\
(0.004)\end{array}$ & $\begin{array}{c}-0.015 * * * \\
(0.004)\end{array}$ & $\begin{array}{c}-0.014 * * * \\
(0.004)\end{array}$ \\
\hline HH Income & $\begin{array}{c}-0.040 * * \\
(0.016)\end{array}$ & $\begin{array}{c}-0.040 * * \\
(0.017)\end{array}$ & $\begin{array}{c}-0.035^{* *} \\
(0.017)\end{array}$ \\
\hline Agriculture & $\begin{array}{c}-0.112 \\
(0.100)\end{array}$ & $\begin{array}{c}-0.114 \\
(0.100)\end{array}$ & $\begin{array}{l}-0.111 \\
(0.101)\end{array}$ \\
\hline Manufacturing Durables & $\begin{array}{c}0.304^{*} \\
(0.182)\end{array}$ & $\begin{array}{c}0.304 * \\
(0.182)\end{array}$ & $\begin{array}{l}0.317^{*} \\
(0.182)\end{array}$ \\
\hline Manufacturing Non-Durables & $\begin{array}{c}0.144 \\
(0.150)\end{array}$ & $\begin{array}{c}0.145 \\
(0.150)\end{array}$ & $\begin{array}{c}0.156 \\
(0.149)\end{array}$ \\
\hline Transportation & $\begin{array}{c}0.297 * * \\
(0.128)\end{array}$ & $\begin{array}{c}0.294 * * \\
(0.128)\end{array}$ & $\begin{array}{c}0.285^{* *} \\
(0.128)\end{array}$ \\
\hline Trade Durables & $\begin{array}{c}-0.021 \\
(0.170)\end{array}$ & $\begin{array}{c}-0.025 \\
(0.169)\end{array}$ & $\begin{array}{c}-0.016 \\
(0.169)\end{array}$ \\
\hline
\end{tabular}

(Continues to next page) 


\begin{tabular}{|c|c|c|c|}
\hline Trade Non-Durables & $\begin{array}{c}0.259 \\
(0.196)\end{array}$ & $\begin{array}{c}0.260 \\
(0.196)\end{array}$ & $\begin{array}{c}0.262 \\
(0.197)\end{array}$ \\
\hline Retail & 0.116 & 0.117 & 0.125 \\
\hline & $(0.106)$ & $(0.107)$ & $(0.107)$ \\
\hline Financial Services & 0.114 & 0.113 & 0.116 \\
\hline & $(0.148)$ & $(0.147)$ & $(0.147)$ \\
\hline Business Services & 0.126 & 0.127 & 0.117 \\
\hline & $(0.093)$ & $(0.093)$ & $(0.093)$ \\
\hline Personal Services & -0.214 & -0.217 & -0.231 \\
\hline & $(0.172)$ & $(0.172)$ & $(0.174)$ \\
\hline Entertainment Services & $-0.398 * *$ & $-0.397 * *$ & $-0.403 * *$ \\
\hline & $(0.167)$ & $(0.168)$ & $(0.168)$ \\
\hline Professional Services & 0.116 & 0.115 & 0.121 \\
\hline & $(0.109)$ & $(0.109)$ & $(0.109)$ \\
\hline Size of Business (1-25 Employees) & $-0.844 * * *$ & $-0.846^{* * *}$ & $-0.837 * * *$ \\
\hline & $(0.067)$ & $(0.067)$ & $(0.067)$ \\
\hline Size of Business (25-99 Employees) & $-1.241 * * *$ & $-1.241 * * *$ & $-1.246 * * *$ \\
\hline & $(0.208)$ & $(0.208)$ & $(0.210)$ \\
\hline State Unemployment Rate & $-0.087 * * *$ & $-0.088 * * *$ & $-0.094 * * *$ \\
\hline & $(0.029)$ & $(0.029)$ & $(0.030)$ \\
\hline Urban Resident & $0.157 * * *$ & $0.156^{* * *}$ & $0.139 * *$ \\
\hline & $(0.059)$ & $(0.059)$ & $(0.060)$ \\
\hline Duration Dependence & & & \\
\hline Month 6-12 & $-0.242 * *$ & $-0.242 * *$ & $-0.244^{* *}$ \\
\hline & $(0.104)$ & $(0.104)$ & $(0.104)$ \\
\hline Month 13-18 & $-0.537 * * *$ & $-0.537 * * *$ & $-0.541^{* * *}$ \\
\hline & $(0.122)$ & $(0.122)$ & $(0.121)$ \\
\hline Month 19-24 & $-0.791 * * *$ & $-0.791 * * *$ & $-0.794 * * *$ \\
\hline & $(0.135)$ & $(0.135)$ & $(0.135)$ \\
\hline Month 25-30 & $-0.924 * * *$ & $-0.924 * * *$ & $-0.930 * * *$ \\
\hline & $(0.147)$ & $(0.147)$ & $(0.147)$ \\
\hline Month 31-36 & $-1.017 * * *$ & $-1.018 * * *$ & $-1.023 * * *$ \\
\hline & $(0.159)$ & $(0.159)$ & $(0.159)$ \\
\hline Month 37-42 & $-1.076 * * *$ & $-1.076^{* * *}$ & $-1.084^{* * *}$ \\
\hline & $(0.168)$ & $(0.168)$ & $(0.168)$ \\
\hline Month 43-48 & $-0.700 * * *$ & $-0.701 * * *$ & $-0.710^{* * *}$ \\
\hline & $(0.151)$ & $(0.151)$ & $(0.151)$ \\
\hline Month 49-54 & $-1.003^{* * *}$ & $-1.004 * * *$ & $-1.015^{* * *}$ \\
\hline & $(0.178)$ & $(0.178)$ & $(0.178)$ \\
\hline Month 55-60 & $-1.062 * * *$ & $-1.063 * * *$ & $-1.074^{* * *}$ \\
\hline & $(0.186)$ & $(0.186)$ & $(0.186)$ \\
\hline Month 61-66 & $-1.117 * * *$ & $-1.118 * * *$ & $-1.129 * * *$ \\
\hline & (0.197) & $(0.197)$ & (0.197) \\
\hline Month 67-72 & $-1.159 * * *$ & $-1.160 * * *$ & $-1.171^{* * *}$ \\
\hline & $(0.205)$ & $(0.205)$ & $(0.205)$ \\
\hline Month 73+ & $-1.159 * * *$ & $-1.159 * * *$ & $-1.168^{* * *}$ \\
\hline & $(0.095)$ & $(0.095)$ & $(0.095)$ \\
\hline Constant & 0.604 & 0.575 & 0.541 \\
\hline & $(0.448)$ & $(0.452)$ & $(0.455)$ \\
\hline Observations & 131717 & 131717 & 131717 \\
\hline
\end{tabular}

Robust standard errors in parentheses. * significant at 10\%; ** significant at 5\%; *** significant at $1 \%$. Year dummies are included in each specification. 


\begin{tabular}{|c|c|c|c|}
\hline & $(1)$ & $(2)$ & (3) \\
\hline Foreign-Born & $\begin{array}{c}0.447 * \\
(0.267)\end{array}$ & & \\
\hline Mexican & & $\begin{array}{c}0.666^{* *} \\
(0.290)\end{array}$ & $\begin{array}{c}0.723 * * \\
(0.290)\end{array}$ \\
\hline Other Hispanic & & $\begin{array}{c}0.679 * * \\
(0.326)\end{array}$ & $\begin{array}{c}0.726^{* *} \\
(0.326)\end{array}$ \\
\hline Asian & & $\begin{array}{c}0.452 \\
(0.317)\end{array}$ & $\begin{array}{c}0.328 \\
(0.328)\end{array}$ \\
\hline European & & $\begin{array}{c}0.290 \\
(0.329)\end{array}$ & $\begin{array}{c}0.490 \\
(0.318)\end{array}$ \\
\hline \multicolumn{4}{|l|}{ U.S.-Born } \\
\hline Mexican & & & $\begin{array}{c}0.176 \\
(0.180)\end{array}$ \\
\hline Other Hispanic & & & $\begin{array}{c}0.268 \\
(0.234)\end{array}$ \\
\hline Asian & & & $\begin{array}{c}-0.014 \\
(0.303)\end{array}$ \\
\hline African American & & & $\begin{array}{c}0.276 * * * \\
(0.107)\end{array}$ \\
\hline Years since Immigration & $\begin{array}{c}-0.066^{* *} \\
(0.033)\end{array}$ & $\begin{array}{c}-0.080 * * \\
(0.034)\end{array}$ & $\begin{array}{c}-0.080 * * \\
(0.034)\end{array}$ \\
\hline Years since Immigration^^2/100 & $\begin{array}{c}0.177 * * \\
(0.084)\end{array}$ & $\begin{array}{c}0.220 * * \\
(0.090)\end{array}$ & $\begin{array}{c}0.220 * * \\
(0.090)\end{array}$ \\
\hline Age & $\begin{array}{c}-0.135^{* * *} \\
(0.018)\end{array}$ & $\begin{array}{c}-0.135^{* * *} \\
(0.018)\end{array}$ & $\begin{array}{c}-0.138 * * * \\
(0.018)\end{array}$ \\
\hline Age $^{\wedge} 2 / 100$ & $\begin{array}{c}0.158^{* * *} \\
(0.021)\end{array}$ & $\begin{array}{c}0.158 * * * \\
(0.021)\end{array}$ & $\begin{array}{c}0.161 * * * \\
(0.021)\end{array}$ \\
\hline High School & $\begin{array}{l}-0.172 * \\
(0.094)\end{array}$ & $\begin{array}{l}-0.145 \\
(0.097)\end{array}$ & $\begin{array}{c}-0.138 \\
(0.097)\end{array}$ \\
\hline College beyond High School & $\begin{array}{c}-0.198 * * \\
(0.095)\end{array}$ & $\begin{array}{l}-0.169 * \\
(0.098)\end{array}$ & $\begin{array}{l}-0.158 \\
(0.099)\end{array}$ \\
\hline College Graduate & $\begin{array}{c}-0.351 * * * \\
(0.105)\end{array}$ & $\begin{array}{c}-0.321^{* * *} \\
(0.108)\end{array}$ & $\begin{array}{c}-0.298 * * * \\
(0.109)\end{array}$ \\
\hline Married & $\begin{array}{l}-0.123 * \\
(0.065)\end{array}$ & $\begin{array}{l}-0.122 * \\
(0.065)\end{array}$ & $\begin{array}{c}-0.109 * \\
(0.065)\end{array}$ \\
\hline No of Kids & $\begin{array}{c}0.002 \\
(0.024)\end{array}$ & $\begin{array}{c}0.000 \\
(0.024)\end{array}$ & $\begin{array}{l}-0.005 \\
(0.024)\end{array}$ \\
\hline HH Wealth & $\begin{array}{c}-0.013 * * * \\
(0.003)\end{array}$ & $\begin{array}{c}-0.013^{* * *} \\
(0.003)\end{array}$ & $\begin{array}{c}-0.012 * * * \\
(0.003)\end{array}$ \\
\hline HH Income & $\begin{array}{c}-0.009 \\
(0.018)\end{array}$ & $\begin{array}{l}-0.009 \\
(0.018)\end{array}$ & $\begin{array}{c}-0.004 \\
(0.018)\end{array}$ \\
\hline Agriculture & $\begin{array}{c}0.046 \\
(0.101)\end{array}$ & $\begin{array}{c}0.045 \\
(0.101)\end{array}$ & $\begin{array}{c}0.040 \\
(0.101)\end{array}$ \\
\hline Manufacturing Durables & $\begin{array}{c}-0.009 \\
(0.185)\end{array}$ & $\begin{array}{c}-0.014 \\
(0.186)\end{array}$ & $\begin{array}{c}-0.020 \\
(0.188)\end{array}$ \\
\hline Manufacturing Non-Durables & $\begin{array}{c}0.114 \\
(0.152)\end{array}$ & $\begin{array}{c}0.115 \\
(0.152)\end{array}$ & $\begin{array}{c}0.123 \\
(0.152)\end{array}$ \\
\hline Transportation & $\begin{array}{c}-0.016 \\
(0.122)\end{array}$ & $\begin{array}{l}-0.016 \\
(0.122)\end{array}$ & $\begin{array}{c}-0.032 \\
(0.122)\end{array}$ \\
\hline Trade Durables & $\begin{array}{c}-0.031 \\
(0.186)\end{array}$ & $\begin{array}{c}-0.032 \\
(0.185)\end{array}$ & $\begin{array}{c}-0.032 \\
(0.186)\end{array}$ \\
\hline
\end{tabular}

(Continues to next page) 


\begin{tabular}{|c|c|c|c|}
\hline Trade Non-Durables & $\begin{array}{c}0.101 \\
(0.188)\end{array}$ & $\begin{array}{c}0.118 \\
(0.188)\end{array}$ & $\begin{array}{c}0.130 \\
(0.188)\end{array}$ \\
\hline \multirow[t]{2}{*}{ Retail } & $-0.182 *$ & $-0.182 *$ & $-0.178 *$ \\
\hline & $(0.107)$ & $(0.108)$ & $(0.108)$ \\
\hline \multirow[t]{2}{*}{ Financial Services } & -0.028 & -0.033 & -0.041 \\
\hline & $(0.139)$ & $(0.139)$ & $(0.139)$ \\
\hline \multirow[t]{2}{*}{ Business Services } & -0.010 & -0.014 & -0.021 \\
\hline & $(0.091)$ & $(0.091)$ & $(0.091)$ \\
\hline \multirow[t]{2}{*}{ Personal Services } & -0.239 & -0.226 & -0.230 \\
\hline & $(0.178)$ & $(0.177)$ & $(0.177)$ \\
\hline \multirow[t]{2}{*}{ Entertainment Services } & -0.247 & -0.244 & -0.248 \\
\hline & $(0.154)$ & $(0.154)$ & $(0.154)$ \\
\hline \multirow[t]{2}{*}{ Professional Services } & 0.014 & 0.015 & 0.012 \\
\hline & $(0.109)$ & $(0.108)$ & $(0.109)$ \\
\hline \multirow[t]{2}{*}{ Size of Business (1-25 Employees) } & $-0.756^{* * *}$ & $-0.758 * * *$ & $-0.752 * * *$ \\
\hline & $(0.064)$ & $(0.064)$ & $(0.064)$ \\
\hline \multirow[t]{2}{*}{ Size of Business (25-99 Employees) } & $-0.847 * * *$ & $-0.847 * * *$ & $-0.851 * * *$ \\
\hline & $(0.213)$ & $(0.213)$ & $(0.214)$ \\
\hline \multirow[t]{2}{*}{ State Unemployment Rate } & -0.003 & -0.005 & -0.011 \\
\hline & $(0.023)$ & $(0.024)$ & $(0.024)$ \\
\hline \multirow[t]{2}{*}{ Urban Resident } & 0.065 & 0.060 & 0.044 \\
\hline & $(0.058)$ & $(0.058)$ & $(0.058)$ \\
\hline \multicolumn{4}{|l|}{ Duration Dependence } \\
\hline \multirow[t]{2}{*}{ Month 6-12 } & $-0.250 * *$ & $-0.250 * *$ & $-0.250 * *$ \\
\hline & $(0.106)$ & $(0.106)$ & $(0.106)$ \\
\hline \multirow[t]{2}{*}{ Month 13-18 } & $-0.521^{* * *}$ & $-0.520 * * *$ & $-0.519 * * *$ \\
\hline & $(0.122)$ & $(0.122)$ & $(0.122)$ \\
\hline \multirow[t]{2}{*}{ Month 19-24 } & $-0.834^{* * *}$ & $-0.833 * * *$ & $-0.834 * * *$ \\
\hline & $(0.136)$ & $(0.136)$ & $(0.136)$ \\
\hline \multirow[t]{2}{*}{ Month 25-30 } & $-0.864 * * *$ & $-0.866 * * *$ & $-0.866 * * *$ \\
\hline & $(0.146)$ & $(0.146)$ & $(0.146)$ \\
\hline \multirow[t]{2}{*}{ Month 31-36 } & $-1.102 * * *$ & $-1.105^{* * *}$ & $-1.100 * * *$ \\
\hline & (0.159) & $(0.159)$ & $(0.159)$ \\
\hline \multirow[t]{2}{*}{ Month 37-42 } & $-1.025^{* * *}$ & $-1.029 * * *$ & $-1.023 * * *$ \\
\hline & $(0.168)$ & $(0.169)$ & $(0.169)$ \\
\hline \multirow[t]{2}{*}{ Month 43-48 } & $-0.729 * * *$ & $-0.733 * * *$ & $-0.730 * * *$ \\
\hline & $(0.150)$ & $(0.150)$ & $(0.150)$ \\
\hline \multirow[t]{2}{*}{ Month 49-54 } & $-0.893 * * *$ & $-0.897 * * *$ & $-0.894 * * *$ \\
\hline & $(0.175)$ & $(0.175)$ & $(0.175)$ \\
\hline \multirow[t]{2}{*}{ Month 55-60 } & $-1.043 * * *$ & $-1.048^{* * *}$ & $-1.043^{* * *}$ \\
\hline & $(0.185)$ & $(0.185)$ & $(0.185)$ \\
\hline \multirow[t]{2}{*}{ Month 61-66 } & $-1.005^{* * *}$ & $-1.011^{* * *}$ & $-1.006^{* * *}$ \\
\hline & (0.195) & $(0.195)$ & $(0.195)$ \\
\hline \multirow[t]{2}{*}{ Month 67-72 } & $-1.196 * * *$ & $-1.203^{* * *}$ & $-1.200 * * *$ \\
\hline & $(0.203)$ & $(0.204)$ & $(0.203)$ \\
\hline Month 73+ & $-1.414^{* * *}$ & $-1.420 * * *$ & $-1.414^{* * *}$ \\
\hline & $(0.094)$ & $(0.094)$ & $(0.093)$ \\
\hline Constant & $-0.806^{*}$ & $-0.828 *$ & $-0.831^{*}$ \\
\hline & $(0.438)$ & $(0.440)$ & $(0.441)$ \\
\hline Observations & 131717 & 131717 & 131717 \\
\hline
\end{tabular}

Robust standard errors in parentheses. * significant at $10 \%$; ** significant at $5 \%$; *** significant at $1 \%$. Year dummies are included in each specification. 


\begin{tabular}{|c|c|c|c|c|c|c|}
\hline \multirow[b]{3}{*}{ Foreign-Born } & \multicolumn{3}{|c|}{ Exit to Employment } & \multicolumn{3}{|c|}{ Exit to Non-Employment } \\
\hline & $(1)$ & $(2)$ & (3) & (4) & (5) & (6) \\
\hline & $\begin{array}{c}0.683 * * \\
(0.310)\end{array}$ & & & $\begin{array}{c}-0.192 \\
(0.552)\end{array}$ & & \\
\hline Mexican & & $\begin{array}{c}1.097 * * * \\
(0.344)\end{array}$ & $\begin{array}{c}1.127 * * * \\
(0.344)\end{array}$ & & $\begin{array}{c}-0.300 \\
(0.519)\end{array}$ & $\begin{array}{l}-0.181 \\
(0.524)\end{array}$ \\
\hline Other Hispanic & & $\begin{array}{c}0.938 * * \\
(0.387)\end{array}$ & $\begin{array}{c}0.965 * * \\
(0.387)\end{array}$ & & $\begin{array}{c}0.041 \\
(0.607)\end{array}$ & $\begin{array}{c}0.139 \\
(0.608)\end{array}$ \\
\hline Asian & & $\begin{array}{c}0.204 \\
(0.396)\end{array}$ & $\begin{array}{c}0.578 \\
(0.388)\end{array}$ & & $\begin{array}{c}0.612 \\
(0.588)\end{array}$ & $\begin{array}{l}-0.323 \\
(0.628)\end{array}$ \\
\hline European & & $\begin{array}{c}0.556 \\
(0.388)\end{array}$ & $\begin{array}{c}0.226 \\
(0.396)\end{array}$ & & $\begin{array}{c}-0.394 \\
(0.624)\end{array}$ & $\begin{array}{c}0.685 \\
(0.594)\end{array}$ \\
\hline \multicolumn{7}{|l|}{ U.S.-Born } \\
\hline Mexican & & & $\begin{array}{c}0.075 \\
(0.226)\end{array}$ & & & $\begin{array}{c}0.287 \\
(0.317)\end{array}$ \\
\hline Other Hispanic & & & $\begin{array}{c}0.281 \\
(0.281)\end{array}$ & & & $\begin{array}{c}0.220 \\
(0.489)\end{array}$ \\
\hline Asian & & & $\begin{array}{c}0.012 \\
(0.351)\end{array}$ & & & $\begin{array}{c}-0.139 \\
(0.689)\end{array}$ \\
\hline African American & & & $\begin{array}{c}0.134 \\
(0.138)\end{array}$ & & & $\begin{array}{c}0.523^{* * *} \\
(0.177)\end{array}$ \\
\hline Years since Immigration & $\begin{array}{c}-0.088^{* *} \\
(0.039)\end{array}$ & $\begin{array}{c}-0.093^{* *} \\
(0.041)\end{array}$ & $\begin{array}{c}-0.093^{* *} \\
(0.041)\end{array}$ & $\begin{array}{c}-0.005 \\
(0.060)\end{array}$ & $\begin{array}{c}-0.045 \\
(0.060)\end{array}$ & $\begin{array}{c}-0.046 \\
(0.060)\end{array}$ \\
\hline Years since Immigration^^2/100 & $\begin{array}{c}0.216^{* *} \\
(0.101)\end{array}$ & $\begin{array}{c}0.235^{* *} \\
(0.109)\end{array}$ & $\begin{array}{c}0.236 * * \\
(0.109)\end{array}$ & $\begin{array}{c}0.059 \\
(0.144)\end{array}$ & $\begin{array}{c}0.175 \\
(0.150)\end{array}$ & $\begin{array}{c}0.174 \\
(0.151)\end{array}$ \\
\hline Age & $\begin{array}{c}-0.099 * * * \\
(0.022)\end{array}$ & $\begin{array}{c}-0.099 * * * \\
(0.022)\end{array}$ & $\begin{array}{c}-0.101^{* * *} \\
(0.022)\end{array}$ & $\begin{array}{c}-0.179 * * * \\
(0.032)\end{array}$ & $\begin{array}{c}-0.176^{* * *} \\
(0.033)\end{array}$ & $\begin{array}{c}-0.183^{* * *} \\
(0.033)\end{array}$ \\
\hline Age $\wedge 2 / 100$ & $\begin{array}{c}0.102^{* * *} \\
(0.027)\end{array}$ & $\begin{array}{c}0.102^{* * *} \\
(0.027)\end{array}$ & $\begin{array}{c}0.104^{* * *} \\
(0.027)\end{array}$ & $\begin{array}{c}0.235^{* * *} \\
(0.037)\end{array}$ & $\begin{array}{c}0.231 * * * \\
(0.038)\end{array}$ & $\begin{array}{c}0.237^{* * *} \\
(0.038)\end{array}$ \\
\hline High School & $\begin{array}{c}0.012 \\
(0.124)\end{array}$ & $\begin{array}{c}0.091 \\
(0.130)\end{array}$ & $\begin{array}{c}0.095 \\
(0.130)\end{array}$ & $\begin{array}{c}-0.399 * * * \\
(0.152)\end{array}$ & $\begin{array}{c}-0.442^{* * *} \\
(0.154)\end{array}$ & $\begin{array}{c}-0.427^{* * *} \\
(0.156)\end{array}$ \\
\hline College beyond High School & $\begin{array}{c}0.074 \\
(0.125)\end{array}$ & $\begin{array}{c}0.150 \\
(0.131)\end{array}$ & $\begin{array}{c}0.157 \\
(0.131)\end{array}$ & $\begin{array}{c}-0.645^{* * *} \\
(0.164)\end{array}$ & $\begin{array}{c}-0.679 * * * \\
(0.167)\end{array}$ & $\begin{array}{c}-0.657^{* * * *} \\
(0.169)\end{array}$ \\
\hline College Graduate & $\begin{array}{c}-0.075 \\
(0.135)\end{array}$ & $\begin{array}{c}0.010 \\
(0.141)\end{array}$ & $\begin{array}{c}0.020 \\
(0.142)\end{array}$ & $\begin{array}{c}-0.819 * * * \\
(0.186)\end{array}$ & $\begin{array}{c}-0.882^{* * *} \\
(0.189)\end{array}$ & $\begin{array}{c}-0.832 * * * \\
(0.193)\end{array}$ \\
\hline Married & $\begin{array}{c}-0.013 \\
(0.078)\end{array}$ & $\begin{array}{l}-0.013 \\
(0.078)\end{array}$ & $\begin{array}{l}-0.008 \\
(0.078)\end{array}$ & $\begin{array}{c}-0.374 * * * \\
(0.118)\end{array}$ & $\begin{array}{c}-0.371^{* * *} \\
(0.119)\end{array}$ & $\begin{array}{c}-0.345^{* * *} \\
(0.119)\end{array}$ \\
\hline No of Kids & $\begin{array}{c}-0.014 \\
(0.029)\end{array}$ & $\begin{array}{c}-0.019 \\
(0.029)\end{array}$ & $\begin{array}{c}-0.021 \\
(0.029)\end{array}$ & $\begin{array}{c}0.042 \\
(0.044)\end{array}$ & $\begin{array}{c}0.044 \\
(0.045)\end{array}$ & $\begin{array}{c}0.034 \\
(0.045)\end{array}$ \\
\hline HH Wealth & $\begin{array}{c}-0.011^{* * *} \\
(0.004)\end{array}$ & $\begin{array}{c}-0.010^{* * *} \\
(0.004)\end{array}$ & $\begin{array}{c}-0.010^{* *} \\
(0.004)\end{array}$ & $\begin{array}{c}-0.018^{* * *} \\
(0.006)\end{array}$ & $\begin{array}{c}-0.018^{* * *} \\
(0.006)\end{array}$ & $\begin{array}{c}-0.016^{* * * *} \\
(0.006)\end{array}$ \\
\hline HH Income & $\begin{array}{c}0.022 \\
(0.024)\end{array}$ & $\begin{array}{c}0.025 \\
(0.024)\end{array}$ & $\begin{array}{c}0.027 \\
(0.024)\end{array}$ & $\begin{array}{c}-0.058 * * \\
(0.027)\end{array}$ & $\begin{array}{c}-0.060 * * \\
(0.027)\end{array}$ & $\begin{array}{l}-0.051^{*} \\
(0.028)\end{array}$ \\
\hline Size of Business (1-25 Employees) & $\begin{array}{c}-0.813^{* * *} \\
(0.076)\end{array}$ & $\begin{array}{c}-0.824^{* * *} \\
(0.076)\end{array}$ & $\begin{array}{c}-0.823^{* * *} \\
(0.077)\end{array}$ & $\begin{array}{c}-0.619 * * * \\
(0.119)\end{array}$ & $\begin{array}{c}-0.616^{* * *} \\
(0.119)\end{array}$ & $\begin{array}{c}-0.592 * * * \\
(0.120)\end{array}$ \\
\hline Size of Business (25-99 Employees) & $\begin{array}{c}-0.658 * * * \\
(0.238)\end{array}$ & $\begin{array}{c}-0.667^{* * *} \\
(0.239)\end{array}$ & $\begin{array}{c}-0.667^{* * *} \\
(0.239)\end{array}$ & $\begin{array}{c}-1.437 * * * \\
(0.513)\end{array}$ & $\begin{array}{c}-1.422^{* * *} \\
(0.513)\end{array}$ & $\begin{array}{c}-1.429 * * * \\
(0.517)\end{array}$ \\
\hline State Unemployment Rate & $\begin{array}{c}-0.008 \\
(0.029)\end{array}$ & $\begin{array}{c}-0.011 \\
(0.029)\end{array}$ & $\begin{array}{c}-0.014 \\
(0.030)\end{array}$ & $\begin{array}{c}0.012 \\
(0.041)\end{array}$ & $\begin{array}{c}0.009 \\
(0.042)\end{array}$ & $\begin{array}{c}-0.002 \\
(0.042)\end{array}$ \\
\hline Urban Resident & $\begin{array}{c}0.074 \\
(0.070)\end{array}$ & $\begin{array}{c}0.069 \\
(0.070) \\
\end{array}$ & $\begin{array}{c}0.061 \\
(0.071)\end{array}$ & $\begin{array}{c}0.046 \\
(0.108)\end{array}$ & $\begin{array}{c}0.046 \\
(0.108) \\
\end{array}$ & $\begin{array}{c}0.009 \\
(0.108) \\
\end{array}$ \\
\hline
\end{tabular}

(Continues to next page) 
Duration Dependence

Month 6-12

$$
\begin{array}{ccc}
-0.208^{*} & -0.208^{*} & -0.207^{*} \\
(0.124) & (0.124) & (0.124) \\
-0.350^{* *} & -0.350^{* *} & -0.349^{* *} \\
(0.138) & (0.138) & (0.138) \\
-0.727^{* * *} & -0.728^{* * *} & -0.728^{* * *} \\
(0.158) & (0.158) & (0.158) \\
-0.854^{* * *} & -0.856^{* * *} & -0.855^{* * *} \\
(0.175) & (0.175) & (0.175) \\
-1.039 * * * & -1.039 * * * & -1.036^{* * *} \\
(0.187) & (0.187) & (0.187) \\
-0.832 * * * & -0.829 * * * & -0.826 * * * \\
(0.188) & (0.188) & (0.188)
\end{array}
$$

$-0.349 * \quad-0.345 * \quad-0.347 *$

Month 13-18

(0.198) (0.198)

$(0.198)$

Month 19-24

Month 25-30

Month 31-36

-1.067*** $-1.061 * * *-1.061 * * *$

$\begin{array}{lll}(0.268) & (0.268) \quad(0.268)\end{array}$

$-1.117 * * *-1.110 * * *-1.115^{* * *}$

$\begin{array}{lll}(0.270) & (0.270) \quad(0.272)\end{array}$

$-0.885^{* * *}-0.882 * * *-0.880 * * *$

Month 37-42

$\begin{array}{lll}-0.701 * * * & -0.703 * * * & -0.700 * * *\end{array}$

$\begin{array}{lll}(0.265) & (0.265) \quad(0.265)\end{array}$

Month 43-48

$\begin{array}{ccc}(0.179) & (0.180) & (0.179) \\ -0.743 * * * & -0.748 * * * & -0.746 * *\end{array}$

Month 49-54

$\begin{array}{ccc}-0.743^{* * *} & -0.748^{* * *} & -0.746 * * * \\ (0.199) & (0.199) & (0.199)\end{array}$

Month 55-60

$-1.002 * * * \quad-1.009 * * * \quad-1.007 * * *$

$-1.258^{* * *}-1.264^{* * *}-1.251^{* * *}$

(0.304) (0.305) (0.305)

$-1.672 * * *-1.683^{* * *}-1.669 * * *$

$\begin{array}{lll}(0.402) & (0.402) \quad(0.402)\end{array}$

$-0.803^{* * *}-0.807 * * * \quad-0.798 * * *$

$\begin{array}{lll}(0.274) & (0.274) \quad(0.273)\end{array}$

$-1.338 * * *-1.337 * * *-1.329 * * *$

(0.375) (0.375) (0.375)

$-1.135^{* * *}-1.136 * * *-1.121 * * *$

Month 61-66

$\begin{array}{lll}(0.221) & (0.221) \quad(0.221)\end{array}$

(0.343) (0.344) (0.344)

$\begin{array}{lll}-0.924 * * * & -0.932 * * * & -0.930 * * *\end{array}$

$-1.205^{* * *}-1.207^{* * *}-1.189 * * *$

$\begin{array}{lll}(0.227) & (0.226) \quad(0.226)\end{array}$

(0.382) (0.382) (0.381)

Month 67-72

$-1.148 * * * \quad-1.159 * * * \quad-1.158 * * *$

$-1.303^{* * *}-1.304^{* * *}-1.295 * * *$

$\begin{array}{lll}(0.242) & (0.242) \quad(0.242)\end{array}$

$-1.477 * * * \quad-1.483^{* * *} \quad-1.479 * * *$

(0.373) (0.373)

(0.373)

Month 73+

(0.116) (0.116) (0.116)

320***-1326*** $-1318 * * *$

Constant

$-2.273 * * * \quad-2.368 * * * \quad-2.369 * * *$

$\begin{array}{lll}(0.165) & (0.166) \quad(0.165)\end{array}$

$\begin{array}{lll}-0.582 & -0.556 & -0.547\end{array}$

$\begin{array}{llllll}(0.543) & (0.549) & (0.550) & (0.764) & (0.763) & (0.765)\end{array}$

Observations

$131717 \quad 131717 \quad 131717$

$131717 \quad 131717 \quad 131717$

Robust standard errors in parentheses. * significant at 10\%; ** significant at 5\%; *** significant at $1 \%$. Year and

sector dummies are included in each specification. 


\begin{tabular}{|c|c|c|}
\hline & Coeff. & s.e. \\
\hline \multicolumn{3}{|l|}{ Foreign-Born } \\
\hline Mexican & 0.677 & $0.306 * *$ \\
\hline Other Hispanic & 0.662 & $0.344 *$ \\
\hline Asian & 0.310 & 0.346 \\
\hline European & 0.406 & 0.339 \\
\hline \multicolumn{3}{|l|}{ U.S.-Born } \\
\hline Mexican & 0.045 & 0.236 \\
\hline Other Hispanic & 0.129 & 0.307 \\
\hline Asian & -0.158 & 0.339 \\
\hline African American & 0.269 & $0.107 * *$ \\
\hline \multicolumn{3}{|l|}{ Duration Dependence } \\
\hline \multicolumn{3}{|l|}{ Foreign-Born } \\
\hline Month 12-24 & -0.469 & 0.289 \\
\hline Month 25-36 & -1.058 & $0.363 * * *$ \\
\hline Month 37-48 & -0.433 & 0.314 \\
\hline Month 49-60 & -0.520 & 0.368 \\
\hline Month 61-72 & -1.590 & $0.597 * * *$ \\
\hline Month 73+ & -0.800 & $0.231 * * *$ \\
\hline \multicolumn{3}{|c|}{ U.S-Born Descendants } \\
\hline Month 12-24 & 0.119 & 0.339 \\
\hline Month 25-36 & -2.002 & $1.004 * *$ \\
\hline Month 37-48 & -0.409 & 0.538 \\
\hline Month 49-60 & -1.175 & 0.716 \\
\hline Month 61-72 & -0.341 & 0.508 \\
\hline Month 73+ & -1.356 & $0.336 * * *$ \\
\hline \multicolumn{3}{|l|}{ U.S.-Born Natives } \\
\hline Month 12-24 & -0.608 & $0.104 * * *$ \\
\hline Month 25-36 & -0.825 & $0.115 * * *$ \\
\hline Month 37-48 & -0.810 & $0.124 * * *$ \\
\hline Month 49-60 & -0.882 & $0.140 * * *$ \\
\hline Month 61-72 & -0.987 & $0.154 * * *$ \\
\hline Month 73+ & -1.352 & $0.087 * * *$ \\
\hline Constant & -0.884 & $0.443 * *$ \\
\hline Observations & \multicolumn{2}{|c|}{131717} \\
\hline
\end{tabular}

Robust standard errors in parentheses. * significant at $10 \%$; ** significant at $5 \%$; *** significant.at $1 \%$. All other regressors as in Table 6 are included in each specification. 